\title{
Integrative taxonomy reveals two new cryptic species of Hyphessobrycon Durbin, 1908 (Teleostei: Characidae) from the Maracaçumé and middle Tocantins River basins, Eastern Amazon region
}

\author{
Erick Cristofore GUIMARÃES ${ }^{1, *}$, Pâmella Silva de BRITO ${ }^{2}$, \\ Pedro Henrique Negreiros BRAGANÇA ${ }^{3}$, Jadson Pinheiro SANTOS ${ }^{4}$, Axel Makay KATZ ${ }^{5}$, \\ Luis Fernando CARVALHO COSTA $^{6} \&$ Felipe Polivanov OTTONI ${ }^{7}$ \\ 1,2,4,7 Universidade Federal do Maranhão, Programa de Pós-Graduação em Biodiversidade e \\ Biotecnologia da Amazônia Legal. Av. dos Portugueses 1966, \\ Cidade Universitária do Bacanga, CEP 65080-805, São Luís, MA, Brazil. \\ ${ }^{3}$ South African Institute for Aquatic Biodiversity, Private Bag 1015, \\ Grahamstown, 6140, South Africa. \\ ${ }^{4}$ Universidade Estadual do Maranhão, Laboratório de Ictiofauna e Piscicultura Integrada, Centro de \\ Ciências Agrárias, Campus Paulo VI, avenida Lourenço Vieira da Silva, \\ n. 1000, bairro Jardim São Cristóvão, CEP 65055-310, São Luís, MA, Brazil. \\ ${ }^{5}$ Universidade Federal do Rio de Janeiro, Laboratório de Sistemática e Evolução de Peixes Teleósteos, \\ Departamento de Zoologia, Instituto de Biologia, Cidade Universitária, \\ CEP 21941-599. Rio de Janeiro, RJ, Brazil. \\ ${ }^{1,2,6}$ Universidade Federal do Maranhão, Departamento de Biologia, Laboratório de Genética e Biologia \\ Molecular, Av. dos Portugueses 1966, Cidade Universitária do Bacanga, \\ CEP 65080-805, São Luís, MA, Brazil. \\ 1,2,7 Universidade Federal do Maranhão, Laboratório de Sistemática e Ecologia de Organismos Aquáticos, \\ Centro de Ciências Agrárias e Ambientais, Centro de Ciências Agrárias e Ambientais (CCAA), campus \\ de Chapadinha, BR-222, KM 04, S/N, Boa Vista, CEP 65500-000, Chapadinha, MA, Brazil.
}

*Corresponding author: erick.ictio@yahoo.com.br

2Email: pamellabrito@hotmail.com

${ }^{3}$ Email: pedrobra88@gmail.com

${ }^{4}$ Email: jadsonpesca@gmail.com

${ }^{5}$ Email: axelmk@gmail.com

6Email:1fecc@yahoo.com.br

${ }^{7}$ Email: fpottoni@gmail.com

\footnotetext{
${ }^{1}$ urn:lsid:zoobank.org:author:67E9AADF-0B92-437E-BB31-6352FBC3F42D

${ }^{2}$ urn:lsid:zoobank.org:author:EBBAE3D2-5BB2-4D2A-8A0D-B2B7CC29DC4F

${ }^{3}$ urn:lsid:zoobank.org:author:59164A3E-8380-4672-A39C-C2FE563F3C4F

${ }^{4}$ urn:lsid:zoobank.org:author:7248FF02-D740-4E2D-A7E0-6A9E81F76974

${ }^{5}$ urn:lsid:zoobank.org:author:31E0031F-15ED-45B3-A0BB-CF985043D3B5

${ }^{6}$ urn:1sid:zoobank.org:author:2AE1615C-3F76-4867-9D7E-2942043F3D06

${ }^{7}$ urn:lsid:zoobank.org:author:6AB34592-DA6D-4AB7-88D8-1F63A97A12E3
} 


\begin{abstract}
Two new species, Hyphessobrycon frickei Guimarães, Brito, Bragança, Katz \& Ottoni sp. nov. and $H$. geryi Guimarães, Brito, Bragança, Katz \& Ottoni sp. nov., are herein described, based on seven different and independent species delimitation methods, and on molecular and morphological characters, making the hypothesis of these new species supported from an integrative taxonomy perspective. They belong to the "Rosy tetra" clade, which is mainly characterized by the presence of a dark brown or black blotch on the dorsal fin and the absence of a midlateral stripe on the body. These two new species are distinguished from the other members of this clade mainly by the arrangement, shape and color pattern of humeral and dorsal-fin spots, as well as by other characters related to scale counts and body pigmentation. The placement of the new species within the "Rosy tetra" clade was based on the combination of morphological character states mentioned above and corroborated by a molecular phylogenetic analysis using the mitochondrial gene cytochrome oxidase subunit 1 . In addition, a new clade (here termed Hyphessobrycon copelandi clade) within the "Rosy tetra" clade is proposed based on molecular data, comprising $H$. copelandi, $H$. frickei sp. nov., $H$. geryi sp. nov. and a still undescribed species. Our results corroborate the occurrence of hidden species within the "Rosy tetra" clade, as suggested by previous studies.
\end{abstract}

Keywords. ABGD, bPTP, DNA barcoding, GMYC, "Rosy tetra” clade.

Guimarães E.C., de Brito P.S., Bragança P.H.N., Brantos J.P., Katz A.M., Carvalho Costa L.F. \& Ottoni F.P. 2020. Integrative taxonomy reveals two new cryptic species of Hyphessobrycon Durbin, 1908 (Teleostei: Characidae) from the Maracaçumé and middle Tocantins River basins, Eastern Amazon region. European Journal of Taxonomy 723: 77-107. https://doi.org/10.5852/ejt.2020.723.1145

\title{
Introduction
}

Hyphessobrycon Durbin, 1908 is one of the most species-rich and widespread characid genus, comprising about 160 valid species and occurring from southern Mexico to the Río de La Plata in Argentina (Fricke et al. 2020a). Despite its non-monophyletic status (Mirande 2010; Oliveira et al. 2011; Betancur-R et al. 2018; Guimarães et al. 2018; Mirande 2018; Guimarães et al. 2019), Hyphessobrycon is one of the genera within Characidae whose species diversity has increased significantly in the past decades. Considering only the last decade, the number of species has risen from 109 to approximately 160, an increase of about $30 \%$ in the number of valid species (Fricke et al. 2020a), and currently comprising approximately $15 \%$ of all characid species (Fricke et al. 2020b).

In the absence of a stable phylogenetic definition, many species have been described and were assigned to Hyphessobrycon based on its traditional diagnosis by Eigenmann $(1917,1918)$. A similar practice has been commonly seen in other Characidae genera, such as Hemigrammus Gill, 1858 and Knodus Eigenmann, 1911 (Javonillo et al. 2010; Oliveira et al. 2011). Although the number of species of Hyphessobrycon has increased substantially, large knowledge gaps persist for the majority of species assigned to the genus, mainly regarding their phylogenetic position, e.g., Hyphessobrycon brumado Zanata \& Camelier, 2010, Hyphessobrycon frankei Zarske \& Géry, 1997, Hyphessobrycon negodagua Lima \& Gerhard, 2001 and Hyphessobrycon werneri Géry \& Uj, 1987.

In an attempt to deal with the high diversity within the genus, species groups were proposed (Géry 1977; Weitzman \& Palmer 1997; García-Alzate et al. 2008; Carvalho \& Malabarba 2015; Ota et al. 2020), such as: Hyphessobrycon groups a-f, "callistus group", "Rosy tetra" clade, Hyphessobrycon heterorhabdus group, Hyphessobrycon sensu stricto, and Hyphessobrycon panamensis species group; some of them probably representing artificial operational assemblages to aid species identification, whereas others could represent potential monophyletic groups, with explicit putative synapomorphies (e.g., Castro-Paz et al. 2014; Bragança et al. 2015; Carvalho \& Malabarba 2015; Guimarães et al. 2018, 2019). 
Recent studies on Neotropical Characiformes, based on molecular data and species delimitation approaches, revealed a high cryptic diversity (e.g., Pereira et al. 2011; Melo et al. 2014; Benine et al. 2015; Benzaquem et al. 2015; Melo et al. 2016a, 2016b, 2016c; García-Melo et al. 2019). Similarly, three recently published papers (e.g., Castro-Paz et al. 2014; Guimarães et al. 2018, 2019) applied molecular species delimitation to investigate the species diversity within the "Rosy tetra" clade, and they all agreed that its taxonomy should be better investigated, since it includes cryptic species.

In addition to the wide distribution and the presence of cryptic species, the confuse taxonomic history of that clade is one of the main challenges when studying its diversity and relationships. The type species of Hemigrammus, H. unilineatus (Gill, 1858), and Pristella Eigenmann 1908, P. maxillaris (Ulrey, 1894), have been historically considered as closely related or belonging to the "Rosy-tetra" clade, which also includes the type species of Hyphessobrycon, H. compressus (Meek, 1904) (Weitzman \& Palmer 1997; Carvalho \& Malabarba 2015). Thus, Hyphessobrycon may be a putative synonym of Hemigrammus (Mirande 2010) or Pristella. However, further studies on the systematics of the species currently assigned to Hyphessobrycon and close related genera are still necessary to clarify this issue (Guimarães et al. 2018, 2019).

The aim of this study is to describe two new cryptic species of Hyphessobrycon sensu Bickford et al. (2006), members of the "Rosy tetra" clade, from the Maracaçumé and middle Tocantins River basins, Eastern Amazon region, based on an integrative taxonomy approach. Furthermore, a new subclade, within the "Rosy tetra" clade, is herein proposed.

\section{Material and methods}

\section{Taxa sampling, specimen collection and preservation}

Specimens were captured with manual trail-net $(2 \mathrm{~m}$ long $\times 1.8 \mathrm{~m}$ high; mesh size: $2 \mathrm{~mm}$ ) and euthanized in a buffered solution of ethyl-3-amino-benzoat-methanesulfonate (MS-222) with a concentration of $250 \mathrm{mg} / \mathrm{l}$ until completely ceasing opercular movements, according to animal welfare laws and guidelines (Close et al. 1996, 1997; Leary et al. 2013). Specimens selected for morphological analysis were fixed in formalin and left for ten days, after which they were preserved in $70 \%$ ethanol. Molecular data were obtained from specimens that were euthanized, fixed and preserved in absolute ethanol. Specimens used for morphological analysis are listed in type and comparative material lists. Specimens for molecular approaches are listed in Table 1. Sequences from other species of Hyphessobrycon and allied species were obtained from the Barcode of Life Database (BOLD) and the National Center for Biotechnology Information (NCBI) databases (Table 1).

\section{Morphological analysis}

Measurements and counts were made according to Fink \& Weitzman (1974). Vertical scale rows between the dorsal-fin origin and the lateral line do not include the scale of the median predorsal series situated just anterior to the first dorsal-fin ray. Counts of supraneurals, vertebrae, procurrent caudal-fin rays, unbranched dorsal- and anal-fin rays, branchiostegal rays, gill-rakers, premaxillary, maxillary, and dentary teeth, and other internal counts were taken only from cleared and stained (C\&S) paratypes, prepared according to Taylor \& Van Dyke (1985). The four modified vertebrae that constitute the Weberian apparatus were not included in the vertebrae counts, and the fused PU1 + U1 was considered as a single element. Osteological nomenclature follows Weitzman (1962). Institutional abbreviations follow Fricke \& Eschmeyer (2020).

\section{DNA extraction, amplification and sequencing analyses}

DNA was extracted from fin clips using Wizard Genomic DNA Purification kit (Promega) according to the manufacturer's protocol. Fragments of the mitochondrial cytochrome 
Table 1 (continued on next two pages). Sampling sites, specimens and DNA sequence information included in the study. Sequences made available by this study are in bold.

\begin{tabular}{|c|c|c|c|}
\hline $\mathbf{N}^{0}$ & Species & GenBank/BoldSystems & Catalog number \\
\hline 1 & Hyphessobrycon flammeus & FUPR988-09 & LBPV-40464 \\
\hline 2 & Hyphessobrycon compressus & FYPM054-10 & CINV-NEC7411 \\
\hline 3 & Hyphessobrycon compressus & MXV767-15 & ECO-CH P 7697 \\
\hline 4 & Hyphessobrycon compressus & MXV765-15 & ECO-CH P 7697 \\
\hline 5 & Hyphessobrycon compressus & MXV766-15 & ECO-CH P 7697 \\
\hline 6 & Hyphessobrycon panamensis & BSFFA760-07 & STRI-05303 \\
\hline 7 & Hyphessobrycon pyrrhonotus & HYP040-13 & INPA 37672-TRO10 \\
\hline 8 & Hyphessobrycon pyrrhonotus & HYP041-13 & INPA 37672-TRO11 \\
\hline 9 & Hyphessobrycon pyrrhonotus & HYP157-13 & JIR2003121101-6469 \\
\hline 10 & Hyphessobrycon pyrrhonotus & HYP158-13 & JIR2003121101-6470 \\
\hline 11 & Hyphessobrycon erythrostigma & HYP076-13 & INPA 37681-HERY1 \\
\hline 12 & Hyphessobrycon erythrostigma & HYP077-13 & INPA37681-HERY10 \\
\hline 13 & Hyphessobrycon erythrostigma & HYP078-13 & INPA 37681-HERY2 \\
\hline 14 & Hyphessobrycon erythrostigma & HYP079-13 & INPA 37681-HERY3 \\
\hline 15 & Hyphessobrycon socolofi & HYP131-13 & INPA 39530-6152 \\
\hline 16 & Hyphessobrycon socolofi & HYP134-13 & INPA 39530-6155 \\
\hline 17 & Hyphessobrycon socolofi & HYP148-13 & INPA 39530-BCR8 \\
\hline 18 & Hyphessobrycon socolofi & HYP135-13 & $\begin{array}{l}\text { INPA 39530-6178 } \\
\text { INPA 39530-6178 }\end{array}$ \\
\hline 19 & Hyphessobrycon bentosi & MK409672 & - \\
\hline 20 & Hyphessobrycon bentosi & MK240340 & CICCAA02350 \\
\hline 21 & Hyphessobrycon bentosi & MK240341 & CICCAA02351 \\
\hline 22 & Hyphessobrycon bentosi & MK240339 & CICCAA02349 \\
\hline 23 & Hyphessobrycon bentosi & HYP117-13 & INPA 39527-BA2 \\
\hline 24 & Hyphessobrycon bentosi & HYP116-13 & INPA 39527-BA1 \\
\hline 25 & Hyphessobrycon bentosi & HYP097-13 & INPA 37684-5939 \\
\hline 26 & Hyphessobrycon bentosi & HYP098-13 & INPA 37684-5940 \\
\hline 27 & Hyphessobrycon piorskii & MG791915 & CICCAA01659-1 \\
\hline 28 & Hyphessobrycon piorskii & MG791914 & CICCAA01651-1 \\
\hline 29 & Hyphessobrycon piorskii & MF765796 & CICCAA00725-1 \\
\hline 30 & Hyphessobrycon piorskii & MF765797 & CICCAA00726-1 \\
\hline 31 & Hyphessobrycon piorskii & MK240337 & CICCAA02164-1 \\
\hline 32 & Hyphessobrycon piorskii & MK240338 & CICCAA0264-4 \\
\hline 33 & Hyphessobrycon caru & MH338230 & CICCAA00748-1 \\
\hline 34 & Hyphessobrycon caru & MH338231 & CICCAA00749-1 \\
\hline 35 & Hyphessobrycon caru & MH338232 & CICCAA02300-1 \\
\hline
\end{tabular}


Table 1 (continued).

\begin{tabular}{|c|c|c|c|}
\hline $\mathbf{N}^{0}$ & Species & GenBank/BoldSystems & Catalog number \\
\hline 36 & Hyphessobrycon caru & MH338233 & CICCAA02301-1 \\
\hline 37 & Hyphessobrycon micropterus & BSB287-10 & - \\
\hline 38 & Hyphessobrycon micropterus & BSB289-10 & - \\
\hline 39 & Hyphessobrycon micropterus & BSB290-10 & - \\
\hline 40 & Hyphessobrycon micropterus & BSB291-10 & - \\
\hline 41 & Hyphessobrycon simulatus & GBOL1771-17 & - \\
\hline 42 & Hyphessobrycon simulatus & GBOL3298-18 & MHNG 2757.080 \\
\hline 43 & Hyphessobrycon simulatus & GBOL3300-18 & MHNG 2759.026 \\
\hline 44 & Hyphessobrycon simulatus & GBOL3301-18 & MHNG 2759.026 \\
\hline 45 & Hyphessobrycon simulatus & GBOL3302-18 & MHNG 2759.035 \\
\hline 46 & Hyphessobrycon eques & DSMIS077-09 & CBG OL 0544 \\
\hline 47 & Hyphessobrycon eques & HYP070-13 & INPA 37678-IC2 \\
\hline 48 & Hyphessobrycon eques & HYP071-13 & INPA 37679-PE1 \\
\hline 49 & Hyphessobrycon eques & HYP072-13 & INPA 37680-AL1 \\
\hline 50 & Hyphessobrycon geryi sp. nov. & MK409673 & CICCAA02047-1 \\
\hline 51 & Hyphessobrycon geryi sp. nov. & MK409674 & CICCAA02047-3 \\
\hline 52 & Hyphessobrycon geryi sp. nov. & MK409675 & CICCAA02047-6 \\
\hline 53 & Hyphessobrycon frickei sp. nov. & MK409676 & CICCAA02302-1 \\
\hline 54 & Hyphessobrycon frickei sp. nov. & MK409677 & CICCAA02302-2 \\
\hline 55 & Hyphessobrycon frickei sp. nov. & MK409678 & CICCAA02302-3 \\
\hline 56 & Hyphessobrycon copelandi & HYP094-13 & INPA 37683-TU1 \\
\hline 57 & Hyphessobrycon copelandi & HYP095-13 & INPA_37683-TU2 \\
\hline 58 & Hyphessobrycon copelandi & HYP096-13 & INPA_37683-TU3 \\
\hline 59 & Hyphessobrycon aff. copelandi & HYP016-13 & INPA_37666-MARA6 \\
\hline 60 & Hyphessobrycon aff. copelandi & HYP017-13 & INPA_37666-MARA7 \\
\hline 61 & Hyphessobrycon aff. copelandi & HYP018-13 & - \\
\hline 62 & Hyphessobrycon aff. copelandi & HYР019-13 & - \\
\hline 63 & Hyphessobrycon epicharis & HYP002-13 & INPA 37665-JUF1 \\
\hline 64 & Hyphessobrycon epicharis & НYP004-13 & INPA_37665-JUF3 \\
\hline 65 & Hyphessobrycon epicharis & HYP005-13 & INPA 37665-JUF4 \\
\hline 66 & Hyphessobrycon epicharis & HYP006-13 & INPA 37665-JUF8 \\
\hline 67 & Hyphessobrycon cf. sweglesi & HYP026-13 & INPA 37668-JAR3 \\
\hline 68 & Hyphessobrycon cf. sweglesi & HYP027-13 & INPA 37668-JAR4 \\
\hline 69 & Hyphessobrycon cf. sweglesi & HYP028-13 & INPA 37668-JAR5 \\
\hline 70 & Hyphessobrycon cf. sweglesi & HYP030-13 & INPA 37668-JAR7 \\
\hline 71 & Hyphessobrycon roseus & GBOL 759-15 & - \\
\hline
\end{tabular}


Table 1 (continued).

\begin{tabular}{llcc}
\hline $\mathbf{N}^{\mathbf{0}}$ & Species & GenBank/BoldSystems & Catalog number \\
\hline 72 & Hyphessobrycon roseus & GBOL1785-17 & - \\
73 & Hyphessobrycon roseus & GBOL760-15 & - \\
74 & Hyphessobrycon roseus & GBOL3336-18 & - \\
75 & Pristella maxillaris & KU568982.1 & - \\
76 & Pristella maxillaris & KU568981.1 & - \\
77 & Pristella maxillaris & TZGAA025-06 & I012-1.3 \\
78 & Pristella maxillaris & TZGAA178-06 & I014-7.4 \\
79 & Moenkhausia hemigrammoides & HYP101-13 & INPA 38532-PR1 \\
80 & Moenkhausia hemigrammoides & HYP102-13 & INPA 38532-PR2 \\
81 & Moenkhausia hemigrammoides & HYP103-13 & INPA 38532-PR3 \\
\hline
\end{tabular}

c oxidase subunit 1 gene were amplified, using the universal primers designed by Ward et al. (2005) (FISHF1 5'-TCAACCAACCACAAAGACATTGGCAC-3'and FISHR1 5'-TAGACTTCTGGGTGGCCAAAGAATCA-3'). Polymerase chain reactions (PCR) comprised a total volume of $15 \mu$ l containing $1 \times$ Polymerase buffer, $1.5 \mathrm{mM} \mathrm{MgCl} 2,200 \mu \mathrm{M}$ dNTP, $0.2 \mathrm{uM}$ of each primer, $1 \mathrm{U}$ of Taq Polymerase (Invitrogen), $100 \eta \mathrm{g}$ of DNA template, and ultrapure water. The PCR cycles were as follows: 2 min at $94^{\circ} \mathrm{C}$, followed by 35 cycles of $94^{\circ} \mathrm{C}$ for $30 \mathrm{~s}, 54^{\circ} \mathrm{C}$ for $30 \mathrm{~s}$, and $72^{\circ} \mathrm{C}$ for $1 \mathrm{~min}$, and $10 \mathrm{~min}$ at $72^{\circ} \mathrm{C}$. Amplicons were purified using Illustra GFX PCR DNA and Gel Purification Kit (GE Healthcare Systems) and sequenced using the forward primer by an outsourced sequencing service at the University of São Paulo, using BigDye Terminator kit ver. 3.1 Cycle Sequencing kit in ABI 3730 DNA Analyser (Applied Biosystems).

\section{Data partition, evolution models, and alignment}

The dataset cytochrome c oxidase subunit 1 (COI) (639 bp). Sequences were aligned using ClustalW (Chenna et al. 2003). The DNA sequences were translated into amino acids residues to test for the presence of premature stop codons or indels using the program MEGA 7 (Kumar et al. 2016). Measure Substitution Saturation tests were performed in DAMBE5 (Xia 2013) according to the algorithm proposed by Xia et al. (2003). The best-fit evolutionary model (GTR $+\mathrm{G})$ was calculated, using the corrected Akaike Information Criterion (AICc) determined by the jModelTest 2.1.7 (Darriba et al. 2012).

\section{Species concept, species delimitation, and diagnoses}

The unified species concept is herein adopted by expressing the conceptual definition shared by all traditional species concepts - "species are (segments of) separately evolving metapopulation lineages" - disentangling operational criterion elements to delimit taxa from species concepts (de Queiroz 2005, 2007). According to this concept, species are treated as hypothetical units and could be tested (detected) by the application of distinct criteria (species delimitation methods) (de Queiroz 2005, 2007). It allows for any method to independently provide evidence about species limits and identities (de Queiroz 2005, 2007).

Seven distinct and independent methods relying on different operational criteria for sp suzu65@gmail. com ecies delimitation, based on morphological and molecular data, were implemented here: PAA, Population Aggregation Analysis (Davis \& Nixon 1992); DBC, DNA barcoding, as proposed by Hebert et al. (2003a, 2003b, 2004a, 2004b); ABGD, Automatic Barcode Gap Discovery (Puillandre et al. 2012); 
WP, a tree-based method as proposed by Wiens \& Penkrot (2002) (following Sites \& Marshall 2003); CBB, a character-based DNA barcoding as proposed by Desalle et al. (2005); as well as two coalescent species delimitation methods termed bPTP, the Bayesian implementation of the Poisson tree processes (Zhang et al. 2013), and GMYC, the General Mixed Yule Coalescent method, single-threshold version (Fujisawa \& Barraclough 2013).

All species delimitation methods here adopted, except PAA that relies only on morphological characters, were performed using cytochrome c oxidase subunit 1 (COI) sequences, since it is a mitochondrial gene with a fast evolutionary rate, thus suitable and widely used for single locus species delimitation approaches (Avise 2000).

\section{Population aggregation analysis (PAA)}

The PAA (Davis \& Nixon 1992) is a character-based method, in which species are delimited by a unique combination of morphological character states occurring in one or more populations (Costa et al. 2014). Basically, the occurrence of the same character state in individuals from different populations is evidence to the presence of a gene flow between them, indicating that all correspond to the same species (lineage), whereas the presence of exclusive character states not shared between individuals belonging to two distinct populations suggests that there is no gene flow between them, thus corresponding to distinct lineages.

\section{Wiens and Penkrot analysis (WP)}

WP is based on the direct inspection of haplotype trees generated by a phylogenetic analysis having as terminals at least two individuals (haplotypes) of each focal species. In this method, the term 'exclusive' is used instead of monophyletic, since the term monophyly is considered inapplicable below the species level (Wiens \& Penkrot 2002). Clustered haplotypes with a concordant geographic distribution forming mutual and well supported clades (exclusive lineages) are considered as strong evidence for species discrimination (absence of gene flow with other lineages). When haplotypes from the same locality fail to cluster together, there is potential evidence for gene flow with other populations (Wiens \& Penkrot 2002). Haplotype tree statistical support was assessed by the posterior probability value, considered as significant at about 0.95 or higher (Alfaro \& Holder 2006). When only one haplotype (specimen) from one putative population was available, the species delimitation was based on the exclusivity of the sister clade of this single haplotype, supported by significant values, allowing us to perform the test in populations with only one haplotype (Wiens \& Penkrot 2002). In addition, the method allows the recognition of nonexclusive lineages as species since their sister clades are exclusive and supported by significant values (Wiens \& Penkrot 2002).

A Bayesian inference-based phylogenetic (BI) tree was estimated in MrBayes (Huelsenbeck \& Ronquist 2001) plugin in Geneious 9.0.5 to reconstruct the evolutionary relationships among terminals using General Time Reversible $(\mathrm{GTR}+\mathrm{G})$ as evolutionary model. The Bayesian tree inference was based on a chain length of 10 million, a burn-in length of 500000 generations subsampling trees every 10000 generations. We used a sequence of Hyphessobrycon flammeus Myers, 1924 as outgroup, and all the other haplotypes were considered as ingroup in our analysis..

\section{Traditional DNA barcoding (DBC)}

We used the Kimura-2-parameters model (K2P) (Kimura 1980) to estimate the pairwise genetic distances between species in MEGA 7 software (Kumar et al. 2016). We used DnaSP ver. 6. (Rozas et al. 2003) to estimate the number of variable sites and haplotypes. We considered a cutoff of $2 \%$ as sufficient to discriminate species, since this threshold is commonly inferred by species delimitations among Neotropical fish species based on COI (Jacobina et al. 2018). 


\section{Character-based DNA barcoding (CBB)}

The CBB is similar to the population aggregation analysis proposed by Davis \& Nixon (1992), but directed to nucleotides as an alternative method for diagnosing taxa through DNA barcodes (De Salle et al.2005), since the original method is based on subjective cut-off distance thresholds for the inference of species limits (Hebert et al. 2003a, 2003b, 2004a, 2004b). This method delimits species by the presence of a unique combination of nucleotides within a site shared by individuals of the same population or group of populations. In addition, species were diagnosed by nucleotide substitutions (Costa et al. 2014; Ottoni et al. 2019). Nucleotide substitutions among lineages were optimized in the Bayesian inference topology using PAUP ver. 4 (Swofford 2002). Each nucleotide substitution is represented by its relative numeric position determined through sequence alignment with the complete mitochondrial genome of Astyanax paranae Eigenmann, 1914 (KX609386.1:5503-7062), followed by the specific nucleotide substitution in parentheses. The results of this analysis are presented in Appendix 2 and the molecular diagnosis sections.

\section{General Mixed Yule Coalescent (GMYC)}

The GMYC is a single locus coalescent phylogeny-based species delimitation approach that relies on the branch length to establish a threshold between speciation and coalescent processes (Fujisawa \& Barraclough 2013). Here we applied the single-threshold version of the method, which usually outperforms the multiple-threshold version (Fujisawa \& Barraclough 2013). Following to the requirements of this method,, the dataset was reduced to include only unique haplotypes of H. piorskii, H. caru, H. geryi sp. nov., H. copelandi Durbin, 1908, H. frickei sp. nov.; H. aff. copelandi, and the outgroup was restricted to Hyphessobrycon bentosi Durbin, 1908. Sequences were aligned using ClustalW (Chenna et al. 2003). The best-fit evolutionary model $(\mathrm{GTR}+\mathrm{G})$ for the reduced dataset was calculated using the corrected Akaike Information Criterion (AICc) determined by the jModelTest ver. 2.1.7 (Darriba et al. 2012). The input ultrametric phylogenetic tree was performed in BEAST ver. 1.8.4 (Drummond et al. 2012), with the following parameters: an uncorrelated relaxed clock with lognormal distribution, a Yule Process as tree prior with 10 million generations and sampling frequency of 1000. The GMYC analysis was performed in the Exelixis Lab's server https://species.h-its.org/gmyc/.

\section{Bayesian implementation of the poisson tree processes (bPTP)}

The bPTP is another single locus coalescent phylogeny-based species delimitation method, but it differs from other unilocus species delimitation coalescent approaches, such as GMYC, because it does not need an ultrametric tree (not relying on branch length to delimit species), thus avoiding errors and computer intensive processes (Zhang et al. 2013). The method assumes that more molecular variability (number of nucleotide substitutions) is expected between haplotypes from different species than within a species (Zhang et al. 2013), establishing a threshold between speciation and coalescent processes. The reduced dataset and the input phylogenetic tree for performing the bPTP was the same used in GMYC species delimitation method, since this method also requires the use of only unique haplotypes, and previously detailed in the GMYC species delimitation method description. The bPTP analysis was performed in the Exelixis Lab's web server http://species.h-its.org/ptp/, following the default parameters except for a $20 \%$ burn-in.

\section{Automatic Barcode Gap Discovery (ABGD)}

The ABGD is a barcode species delimitation method that aims to establish a minimum gap that probably corresponds to the threshold between interspecific and intraspecific processes (Puillandre et al. 2012). The major advantage of ABGD when compared to the other barcode species delimitation methods is that the inference of the limit between interspecific and intraspecific processes (gap detection) is recursively applied to previously obtained groups to get finer partitions until there is no 
further partitioning, allowing a more refined search. Basically, the ABGD analysis indicates the number of groups (species) estimated relative to a large spectrum of $p$ values (prior intraspecific values) in which a 0.1 value assumes a maximum intraspecific variability indicating that all sequences belong to only one species, whereas a 0.001 value assumes a very small intraspecific variability indicating that each distinct haplotype represents a different species. After running the ABGD, additional molecular, morphological or ecological characters are needed to infer the correct number of species, following an integrative taxonomy perspective. The ABGD analysis was performed on the ABGD server website https://bioinfo.mnhn.fr/abi/public/abgd/abgdweb.html following the default parameters.

\title{
Results
}

\section{Description of new species}

\author{
Order Characiformes Regan, 1911 \\ Family Characidae Latreille, 1825 \\ Genus Hyphessobrycon Durbin, 1908
}

\begin{abstract}
Hyphessobrycon frickei Guimarães, Brito, Bragança, Katz \& Ottoni sp. nov. urn:1sid:zoobank.org:act:6FECEAF1-EBFC-4978-9861-E502AB12A5C5
\end{abstract}

Fig. 1, Table 2

\section{Morphological Diagnosis (PAA)}

Hyphessobrycon frickei Guimarães, Brito, Bragança, Katz \& Ottoni sp. nov. clearly differs from most of its congeners, except members of the "Rosy tetra" clade, by the presence of a dark brown or black blotch on the dorsal fin (vs absence) and the absence of a midlateral stripe on the body (vs presence). The new species differs from most of its congeners within the "Rosy tetra" clade by possessing a conspicuous small, slightly vertical and elliptical humeral spot (Fig. 1) (vs inconspicuous vertically elongated) humeral spot in Hyphessobrycon bentosi Durbin, 1908, H. caru Guimarães, De Brito, Feitosa, Carvalho-Costa, Ottoni, 2018, H. hasemani Fowler, 1913, H. piorskii Guimarães, De Brito, Feitosa, Carvalho-Costa, Ottoni, 2018; an approximately rounded humeral spot in $H$. erythrostigma (Fowler, 1943), H. jackrobertsi Zarske, 2014, H. minor Durbin, 1909, H. pando Hein, 2009, H. paepkei Zarske, 2014, H. pyrrhonotus Burgess, 1993, H. roseus (Géry, 1960), H. socolofi Weitzman, 1977, and H. sweglesi (Géry, 1961); a conspicuous horizontal or posteriorly elongated humeral spot in H. epicharis Weitzman \& Palmer, 1997, H. khardinae Zarske, 2008, and H. werneri Géry \& Uj, 1987; a large vertical conspicuous humeral spot at least on males in H. eques (Steindachner, 1882), H. haraldschultzi Travassos, 1960, H. micropterus (Eigenmann, 1915), H. megalopterus (Eigenmann, 1915), H. simulatus (Géry, 1960) and H. takasei Géry, 1964; and the absence of a humeral spot in H. compressus (Meek, 1904), H. dorsalis Zarske, 2014, H. georgettae Géry, 1961, H. pulchripinnis Ahl, 1937, and H. rosaceus Durbin, 1909 (see Guimarães et al. 2019: fig. 2). The new species furthermore differs from H. copelandi Durbin, 1908 and H. haraldschultzi Travassos, 1960 by the number of scales on the lateral series (33-37 vs 29-31, 28-30 lateral line scales, respectively); and from $H$. geryi Guimarães, Brito, Bragança, Katz \& Ottoni sp. nov. by the number of horizontal scale rows between the lateral line and pelvic-fin origin (3 vs 4-5, modally 4). Furthermore, H. frickei sp. nov differs from H. geryi sp. nov. by the absence of conspicuous dark chromatophores on opercular zone (vs presence); the absence of conspicuous dark chromatophores on the region posterior to the humeral spot (vs presence, extending to the end of the caudal peduncle); the absence of a thin vertical line, formed by a concentration of dark chromatophores at the middle of the humeral spot, extending to one to two scales above and below the spot (vs presence); and dorsal-fin base less pigmented (vs conspicuous pigmentation on dorsal-fin base) (see Figs 1, 4-5). 


\section{Molecular diagnosis (CBB)}

Hyphessobrycon frickei Guimarães, Brito, Bragança, Katz \& Ottoni sp. nov. is a member of the H. copelandi clade, possessing the following 25 nucleotide substitutions: $\mathrm{COI} 90(\mathrm{C} \rightarrow \mathrm{A}), \mathrm{COI} 126$ $(\mathrm{A} \rightarrow \mathrm{G})$, COI $138(\mathrm{C} \rightarrow \mathrm{T})$, COI $189(\mathrm{C} \rightarrow \mathrm{T})$, COI $192(\mathrm{~T} \rightarrow \mathrm{A})$, COI $237(\mathrm{C} \rightarrow \mathrm{T})$, COI $264(\mathrm{~T} \rightarrow \mathrm{C})$, COI $282(\mathrm{C} \rightarrow \mathrm{T})$, COI $285(\mathrm{C} \rightarrow \mathrm{A})$, COI $312(\mathrm{~T} \rightarrow \mathrm{C})$, COI $384(\mathrm{C} \rightarrow \mathrm{T})$, COI $402(\mathrm{~A} \rightarrow \mathrm{G}), \mathrm{COI} 429$ $(\mathrm{A} \rightarrow \mathrm{G})$, COI $435(\mathrm{~A} \rightarrow \mathrm{G})$, COI $486(\mathrm{~T} \rightarrow \mathrm{C})$, COI $522(\mathrm{~A} \rightarrow \mathrm{G})$, COI $525(\mathrm{C} \rightarrow \mathrm{T})$, COI $547(\mathrm{C} \rightarrow \mathrm{T})$, COI $582(\mathrm{~T} \rightarrow \mathrm{C})$, COI $621(\mathrm{~T} \rightarrow \mathrm{C})$, COI $624(\mathrm{~A} \rightarrow \mathrm{G}), \quad$ COI $678(\mathrm{~T} \rightarrow \mathrm{C})$, COI $684(\mathrm{~A} \rightarrow \mathrm{C})$, COI 690 $(\mathrm{T} \rightarrow \mathrm{C})$, COI $696(\mathrm{~A} \rightarrow \mathrm{G})$. In addition, it differs from $H$. geryi sp. nov. by possessing the following nine nucleotide substitutions: COI $231(\mathrm{~T} \rightarrow \mathrm{C})$, COI $315(\mathrm{~A} \rightarrow \mathrm{G})$, COI $345(\mathrm{~A} \rightarrow \mathrm{C})$, COI $375(\mathrm{G} \rightarrow \mathrm{A})$, $\mathrm{COI} 402(\mathrm{G} \rightarrow \mathrm{A})$, COI $405(\mathrm{~T} \rightarrow \mathrm{C})$, COI $528(\mathrm{~A} \rightarrow \mathrm{G})$, COI $558(\mathrm{~A} \rightarrow \mathrm{G})$, COI $609(\mathrm{~A} \rightarrow \mathrm{G})$; and from A. copelandi by possessing the following eleven nucleotide substitutions: $\mathrm{COI} 126(\mathrm{G} \rightarrow \mathrm{A})$, COI 141 $(\mathrm{G} \rightarrow \mathrm{C})$, COI $291(\mathrm{~A} \rightarrow \mathrm{G}), \mathrm{COI} 300(\mathrm{~A} \rightarrow \mathrm{G}), \mathrm{COI} 345(\mathrm{C} \rightarrow \mathrm{G}), \mathrm{COI} 366(\mathrm{C} \rightarrow \mathrm{T}), \mathrm{COI} 435(\mathrm{G} \rightarrow \mathrm{A}), \mathrm{COI}$ $510(\mathrm{~T} \rightarrow \mathrm{C})$, COI $633(\mathrm{~T} \rightarrow \mathrm{C})$, COI $657(\mathrm{C} \rightarrow \mathrm{T})$, COI $672(\mathrm{~T} \rightarrow \mathrm{C})$.

\section{Etymology}

The new species is named after the ichthyologist Ronald Fricke, in recognition of his contribution to ichthyology.

\section{Material examined}

\section{Holotype}

BRAZIL • 18.8 mm SL; Maranhão State, Maracaçumé municipality, Maracaçumé River; 2³'14" S, 45 57'16" W; 29 Jan. 2017; E.C. Guimarães and P.S. Brito leg; CICCAA 02363

\section{Paratypes}

BRAZIL • 10 specs; $14.8-19.6$ mm SL; Maranhão State, Maracaçumé municipality; stream tributary to

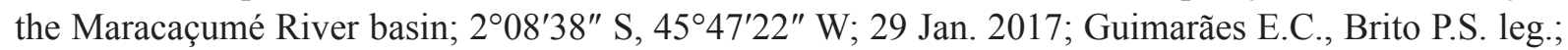
CICCAA 02362 - 5 specs; $15.5-17.7 \mathrm{~mm}$ SL (C\&S); same collection data as for preceding; collected with holotype; CICCAA $02388 \bullet 1$ spec.; $17.8 \mathrm{~mm}$ SL; same collection data as for preceding; UFRJ 6918.

\section{Type locality}

Maracaçumé River basin, a coastal river in the Maranhão state, northeastern Brazil (Fig. 3).

\section{Description}

Morphometric data of holotype and paratypes are presented in Table 2.

Body. Small (larger specimen with $19.6 \mathrm{~mm}$ of SL), laterally compressed, moderately deep, greatest body depth slightly anterior to dorsal-fin base; body profile straight and downward directed from the end of dorsal fin to adipose fin, straight or slightly convex between latter point and origin of dorsal most procurrent caudal-fin ray; dorsal profile of head convex from upper lip to vertical through eye; predorsal profile of body roughly straight, dorsal-fin base slightly convex, posteroventrally inclined; ventral profile of head convex from lower jaw to pelvic-fin origin; straight and posterodorsally slanted along anal-fin base; and slightly concave on caudal peduncle. Jaws equal, mouth terminal. Maxilla reaching vertical to anterior margin of pupil.

TeEth. Premaxillary teeth in two rows. Outer row with two tricuspid teeth; inner row with 3(10), pentacuspid teeth and 3(7) or 2(3) tricuspid teeth. Maxilla with 2(5) or 3(6) tricuspid teeth. Dentary with five (10) larger pentacuspid teeth followed by five (8) or six (2) smaller tricuspid teeth tooth (Fig. 2). 


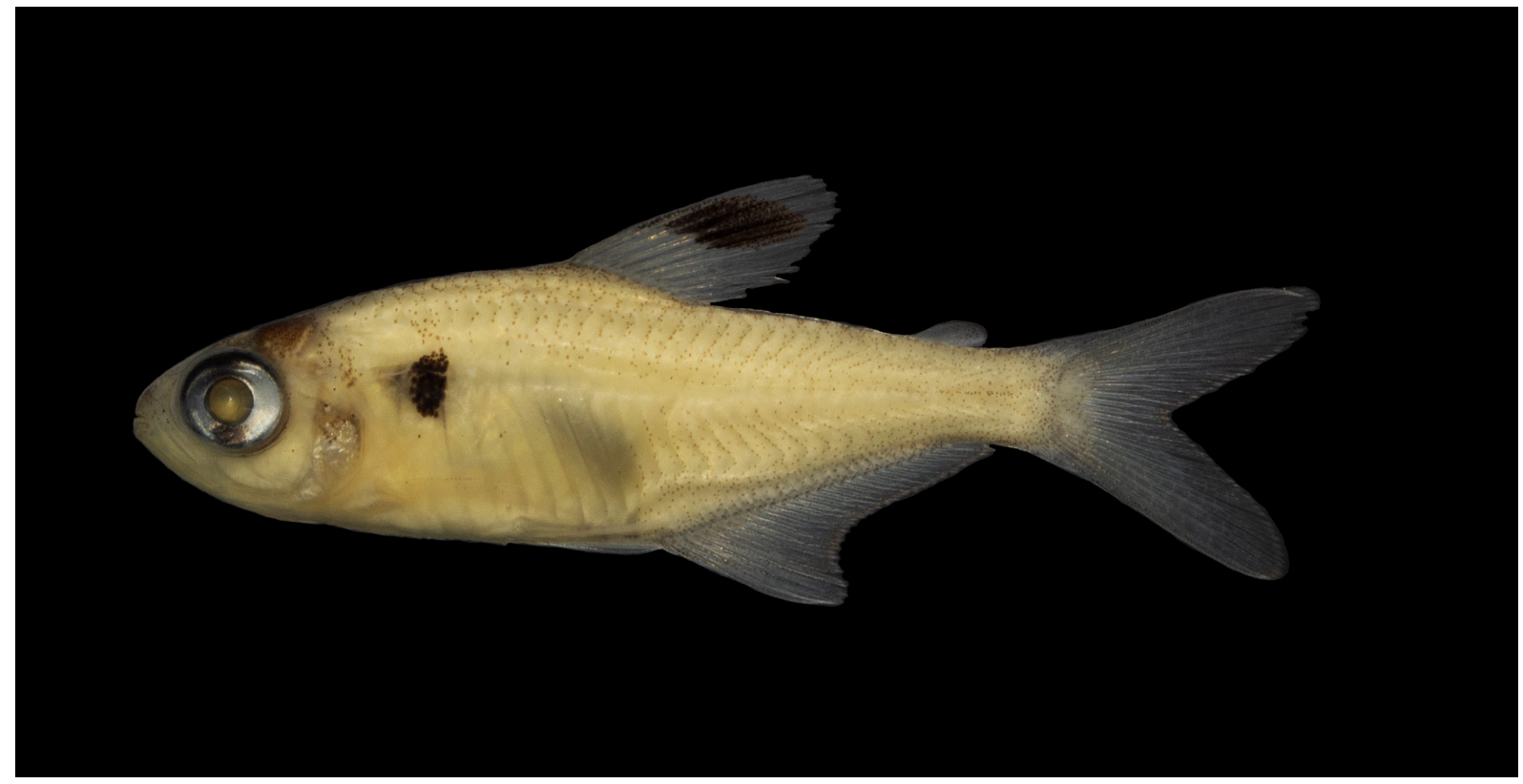

Fig. 1. Hyphessobrycon frickei Guimarães, Brito, Bragança, Katz \& Ottoni sp. nov., holotype (CICCAA 02363), 18.8 mm SL; Brazil: Maranhão State: Maracaçumé River basin.

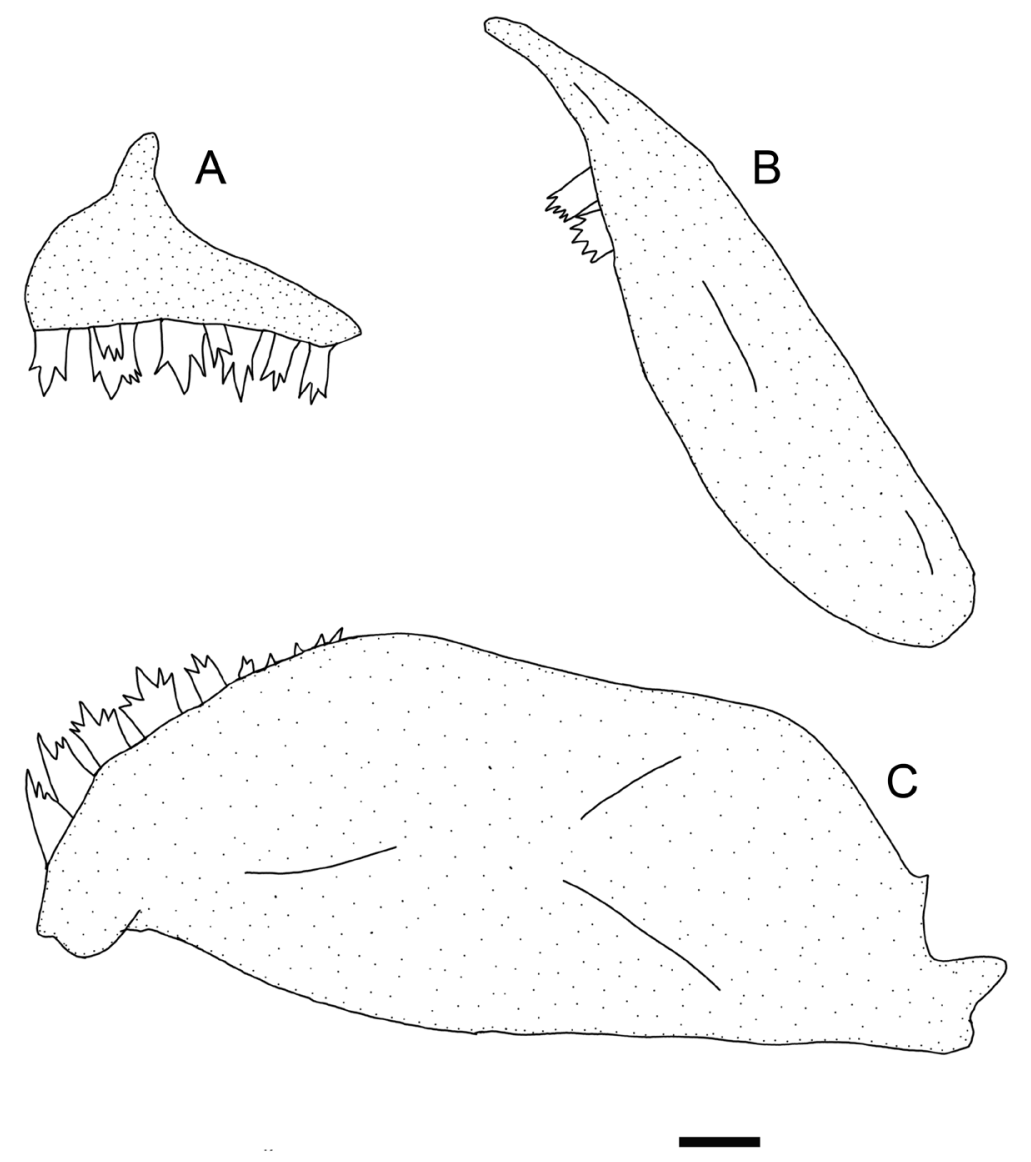

Fig. 2. Hyphessobrycon frickei Guimarães, Brito, Bragança, Katz \& Ottoni sp. nov. (CICCAA 02388), 17.7 mm SL; jaw suspensory. A. Premaxillary. B. Maxilla. C. Dentary. Scale bar: $1 \mathrm{~mm}$ 
Table 2. Morphometric data $(\mathrm{N}=18)$ for the holotype and paratypes of Hyphessobrycon frickei Guimarães, Brito, Bragança, Katz \& Ottoni sp. nov., SD = Standard deviation.

\begin{tabular}{lcccc}
\hline \multicolumn{1}{l}{} & Holotype & Paratypes & Mean & SD \\
\hline Standard length & 18.8 & $14.8-19.6$ & 17.4 & - \\
& Percentages of standard length & & & \\
Depth at dorsal-fin origin (body depth) & 30.8 & $28.4-32.8$ & 30.5 & 1.2 \\
Snout to dorsal-fin origin & 50.7 & $47.2-52.1$ & 50.0 & 1.2 \\
Snout to pectoral-fin origin & 28.6 & $26.2-30.7$ & 28.2 & 1.4 \\
Snout to pelvic-fin origin & 44.6 & $43.1-47.5$ & 45.1 & 1.3 \\
Snout to anal-fin origin & 58.5 & $57.0-62.2$ & 59.3 & 1.4 \\
Caudal peduncle depth & 9.7 & $8.6-11.0$ & 10.0 & 0.7 \\
Caudal peduncle length & 11.4 & $9.1-12.1$ & 10.4 & 0.9 \\
Pectoral-fin length & 20.4 & $17.5-22.7$ & 19.6 & 1.3 \\
Pelvic-fin length & 17.1 & $16.0-19.3$ & 17.3 & 0.9 \\
Dorsal-fin base length & 14.7 & $13.5-16.3$ & 14.8 & 1.0 \\
Dorsal-fin height & 27.4 & $27.2-33.1$ & 29.1 & 1.6 \\
Anal-fin base length & 33.2 & $30.8-35.3$ & 33.1 & 1.0 \\
Eye to dorsal-fin origin & 35.6 & $32.5-37.3$ & 34.4 & 1.1 \\
Dorsal-fin origin to caudal-fin base & 56.5 & $51.1-56.3$ & 53.4 & 1.4 \\
Head length & 28.2 & $26.7-30.9$ & 28.7 & 1.2 \\
& Percentages of head length & & & \\
Horizontal eye diameter & 41.8 & $40.6-45.9$ & 42.7 & 1.6 \\
Snout length & 22.8 & $17.5-24.0$ & 21.6 & 1.9 \\
Least interorbital width & 25.7 & $24.1-30.6$ & 27.4 & 1.7 \\
Upper jaw length & 36.5 & $33.2-37.6$ & 35.3 & 1.6 \\
\hline
\end{tabular}

SCALEs. Scales cycloid, three to eight radii strongly marked, circuli well-marked anteriorly, weakly marked posteriorly; lateral line incompletely pored, with $7(6), 8(7)^{*}, 9(3)$ or $10(1)$ perforated scales. Longitudinal scales series including lateral-line (perforated) scales 33(1), 34(1), 35(3), 36(7)* or 37(1). Longitudinal scales rows between dorsal-fin origin and lateral line 5(1) or 6(16)*. Horizontal scale rows between lateral line and pelvic-fin origin $3(17)^{*}$. Scales in median series between tip of supraoccipital spine and dorsal-fin origin 8(3) or 9(14). Circumpeduncular scales 10(12)*, 11(3) or 12(2).

Fins. Dorsal-fin origin at midbody. Base of last dorsal-fin ray at vertical through first third of anal-fin. Dorsal-fin rays ii $+9(10)^{*}$, iii $+9(5)$, ii $+10(2)$. First dorsal fin pterygiophore main body located behind neural spine of $4^{\text {th }}$ vertebrae. Adipose fin present. Anal-fin origin aligned with vertical line through middle of dorsal-fin, between $6^{\text {th }}$ and $8^{\text {th }}$ dorsal-fin rays. Anteriormost anal-fin pterygiophore inserting posterior to haemal spine of $11^{\text {th }}$ vertebrae. Anal-fin origin aligned with vertical line through middle of dorsal fin (between base of $6^{\text {th }}$ and $8^{\text {th }}$ dorsal-fin rays). Anal fin iii $+22(10)^{*}$ or iii $+23(7)$; anterior anal-fin margin slightly convex, with anteriormost rays more elongate and slightly more thickened than remaining rays, forming a distinct lobe. Remaining rays smaller with straight distal margin. Pectoral-fin rays $12(17)^{*}$. Tip of pectoral fin surpassing pelvic-fin base. Pelvic-fin rays $8(17)^{*}$, surpassing anal-fin 
origin. Caudal fin forked, upper and lower lobes similar in size. Principal caudal fin rays $11+10(10)^{*}$ or $10+9(7)$; dorsal procurrent rays $8(2)$ or $9(3)$ and ventral procurrent rays $7(2)$ or $8(3)$.

Osteological counts. Branchiostegal rays 4(5). First gill arch with 1(4), 2(1) hypobranchial, 11(1), 12(3), or 13(1) ceratobranchial, 1(5) cartilage between ceratobranchial and epibranchial, and 5(1) or 6(4) epibranchial gill-rakers. Supraneurals 4(4) or 5(1). Precaudal vertebrae 11 (5) and caudal vertebrae 19 (5). Total vertebrae 30(5).

\section{Coloration in alcohol (Fig. 1)}

Ground coloration light yellowish brown. Humeral spot conspicuous, slightly vertically elliptical. Flank with inconspicuous chromatophores, more concentrated on dorsal and ventral regions; middle region without or with inconspicuous chromatophores. Ventral region lacking dark brown chromatophores. Dark brown chromatophores present on dorsal portion of head and tip of snout, becoming sparser or absent on opercular region, and absent on cheek. Dorsal-fin ground coloration hyaline, with conspicuous black or dark brown spot located on anterior portion of fin, reaching about $6^{\text {th }}$ ray, approximately between half to two thirds of fin depth. Dorsal-fin base with inconspicuous scattered chromatophores. Anal and caudal fins hyaline. Anal and caudal fins with a darker, usually dark brown, posterior margin. Adipose fin hyaline to light brown, with dark chromatophores at margin and posterior portion. Pectoral and pelvic fins hyaline; pelvic fin with variable amounts of dark brown pigmentation remaining depending on specimen preservation state.

\section{Sexual dimorphism}

Bony hooks on fins are absent in all examined specimens. According to Malabarba \& Weitzman (2003), the presence of bony hooks is a common dimorphic feature among characid species. Although this sexual dimorphism is not observed in all characid species, as in the case of the species described here.

Color pattern is not sexually dimorphic either.

Hyphessobrycon geryi Guimarães, Brito, Bragança, Katz \& Ottoni sp. nov. urn:1sid:zoobank.org:act:75667753-6AB4-4E18-BBD6-3C33ECE68CD4

Figs 4-6, Table 3

\section{Morphological diagnosis (PAA)}

Hyphessobrycon geryi Guimarães, Brito, Bragança, Katz \& Ottoni sp. nov. clearly differs from most of its congeners, except members of the "Rosy tetra" clade, by the presence of a dark brown or black blotch on the dorsal fin (vs absence) and the absence of a midlateral stripe on the body (vs presence). The new species differs from most of its congeners from the "Rosy tetra" clade by possessing a conspicuous small slightly vertical elliptical humeral spot (Fig. 1) (vs inconspicuous vertically elongated) humeral spot in Hyphessobrycon bentosi Durbin, 1908, H. caru Guimarães, De Brito, Feitosa, Carvalho-Costa, Ottoni, 2018, H. hasemani Fowler, 1913, H. piorskii Guimarães, De Brito, Feitosa, Carvalho-Costa, Ottoni, 2018; approximately rounded humeral spot in H. erythrostigma (Fowler, 1943), H. jackrobertsi Zarske, 2014, H. minor Durbin, 1909, H. pando Hein, 2009, H. paepkei Zarske, 2014, H. pyrrhonotus Burgess, 1993, H. roseus (Géry, 1960), H. socolofi Weitzman, 1977, and H. sweglesi (Géry, 1961); humeral spot horizontally or posteriorly elongated in H. epicharis Weitzman \& Palmer, 1997, H. khardinae Zarske, 2008, and H. werneri Géry \& Uj, 1987; large vertical conspicuous humeral spot at least on males in H. eques (Steindachner, 1882), H. haraldschultzi Travassos, 1960, H. micropterus (Eigenmann, 1915), H. megalopterus (Eigenmann, 1915), H. simulatus (Géry, 1960) and H. takasei Géry, 1964; and absence of humeral spot in H. compressus (Meek, 1904), H. dorsalis Zarske, 2014, H. georgettae Géry, 1961, H. pulchripinnis Ahl, 1937, and H. rosaceus Durbin, 1909 (Guimarães et al. 2019: fig. 2). The new species herein described differs from H. copelandi Durbin, 1908, H. haraldschultzi Travassos, 
1960 by the number of lateral series of scales (34-37 vs 29-31, 28-30 lateral line scales, respectively); from $H$. frickei Guimarães, Brito, Bragança, Katz \& Ottoni sp. nov. by the number of horizontal scale rows between lateral line and pelvic-fin origin (4-5, modally 4 vs 3); presence of conspicuous dark chromatophores on opercular zone (vs absence); presence of conspicuous dark chromatophores on the region posterior to humeral spot, extending to the end of caudal peduncle (vs absence); presence of a thin vertical line, formed by the concentration of dark chromatophores, at middle of humeral spot, extending one to two scales above and below the spot (vs absence); and dorsal-fin base with conspicuous pigmentation (vs less pigmented) (see Figs 1, 4-5).

\section{Molecular diagnosis (CBB)}

Hyphessobrycon geryi Guimarães, Brito, Bragança, Katz \& Ottoni sp. nov. is a member of the H. copelandi clade, possessing the following 25 nucleotide substitutions: $\mathrm{COI} 90(\mathrm{C} \rightarrow \mathrm{A})$, COI 126 $(\mathrm{A} \rightarrow \mathrm{G}), \mathrm{COI} 138(\mathrm{C} \rightarrow \mathrm{T}), \mathrm{COI} 189(\mathrm{C} \rightarrow \mathrm{T}), \mathrm{COI} 192(\mathrm{~T} \rightarrow \mathrm{A}), \mathrm{COI} 237(\mathrm{C} \rightarrow \mathrm{T}), \mathrm{COI} 264(\mathrm{~T} \rightarrow \mathrm{C}), \mathrm{COI}$ $282(\mathrm{C} \rightarrow \mathrm{T})$, COI $285(\mathrm{C} \rightarrow \mathrm{A}), \mathrm{COI} 312(\mathrm{~T} \rightarrow \mathrm{C})$, COI $384(\mathrm{C} \rightarrow \mathrm{T}), \mathrm{COI} 402(\mathrm{~A} \rightarrow \mathrm{G}), \mathrm{COI} 429(\mathrm{~A} \rightarrow \mathrm{G})$, $\mathrm{COI} 435(\mathrm{~A} \rightarrow \mathrm{G}), \mathrm{COI} 486(\mathrm{~T} \rightarrow \mathrm{C})$, COI $522(\mathrm{~A} \rightarrow \mathrm{G})$, COI $525(\mathrm{C} \rightarrow \mathrm{T})$, COI $547(\mathrm{C} \rightarrow \mathrm{T})$, COI 582 $(\mathrm{T} \rightarrow \mathrm{C})$, COI $621(\mathrm{~T} \rightarrow \mathrm{C})$, COI $624(\mathrm{~A} \rightarrow \mathrm{G})$, COI $678(\mathrm{~T} \rightarrow \mathrm{C})$, COI $684(\mathrm{~A} \rightarrow \mathrm{C})$, COI $690(\mathrm{~T} \rightarrow \mathrm{C}), \mathrm{COI}$ $696(\mathrm{~A} \rightarrow \mathrm{G})$. In addition, it differs from the other species of this group by the following eight nucleotide substitutions: COI $225(\mathrm{~T} \rightarrow \mathrm{C})$, COI $228(\mathrm{~A} \rightarrow \mathrm{C})$, COI $321(\mathrm{G} \rightarrow \mathrm{A})$, COI $522(\mathrm{G} \rightarrow \mathrm{A})$, COI $534(\mathrm{G} \rightarrow \mathrm{A})$, COI $543(\mathrm{~A} \rightarrow \mathrm{G})$, COI $589(\mathrm{C} \rightarrow \mathrm{T})$, COI $615(\mathrm{G} \rightarrow \mathrm{A})$.

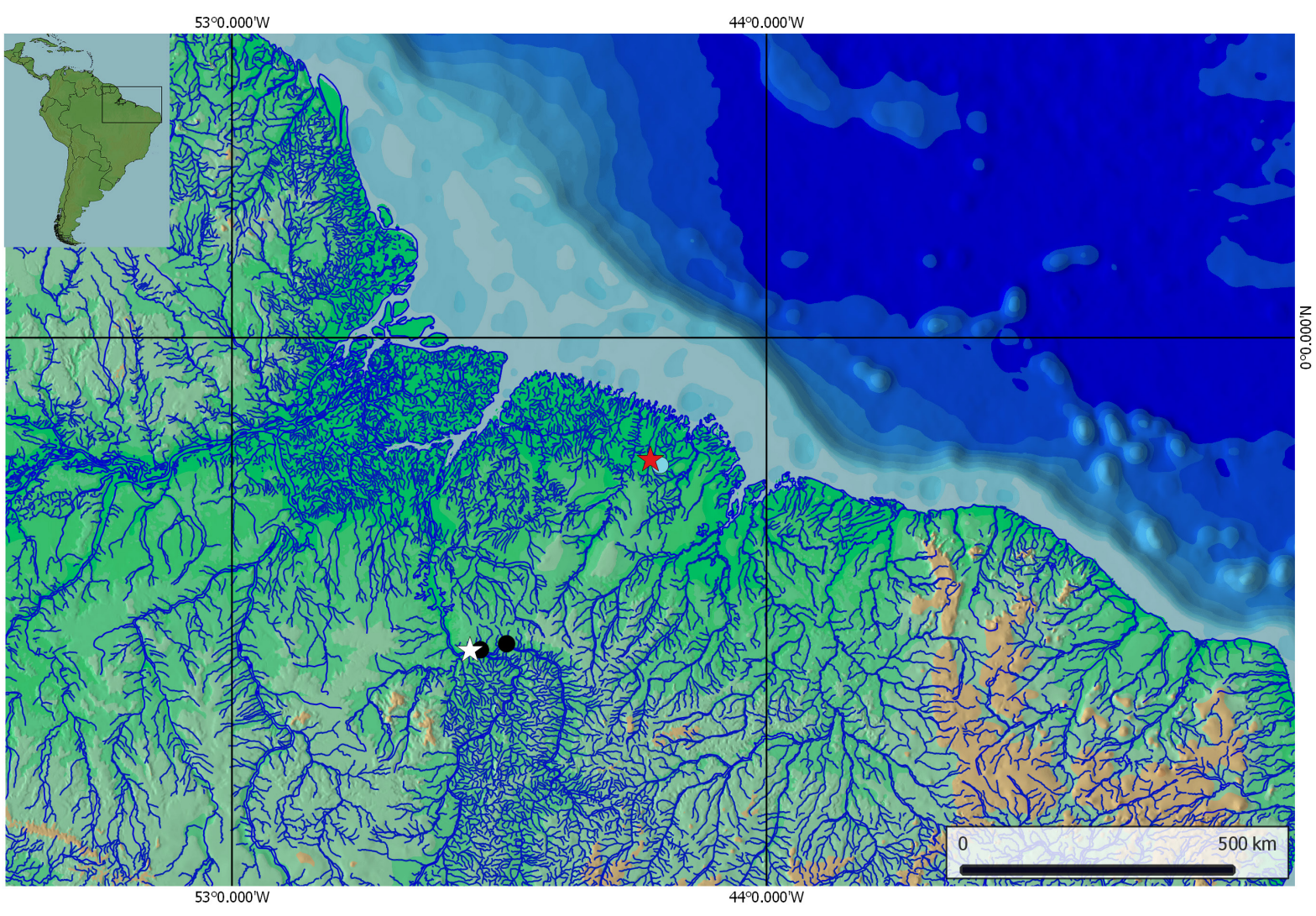

Fig. 3. Geographical distribution of Hyphessobrycon frickei Guimarães, Brito, Bragança, Katz \& Ottoni sp. nov. and H. geryi Guimarães, Brito, Bragança, Katz \& Ottoni sp. nov. Red star denotes holotype and blue circle denotes paratypes of $H$. frickei Guimarães, Brito, Bragança, Katz \& Ottoni sp. nov. whereas white star denotes holotype and the black circles denote paratypes of $H$. geryi Guimarães, Brito, Bragança, Katz \& Ottoni sp. nov. 


\section{Etymology}

The new species is named after the ichthyologist Jacques Géry (in memoriam) in recognition of his scientific contribution on Characiformes.

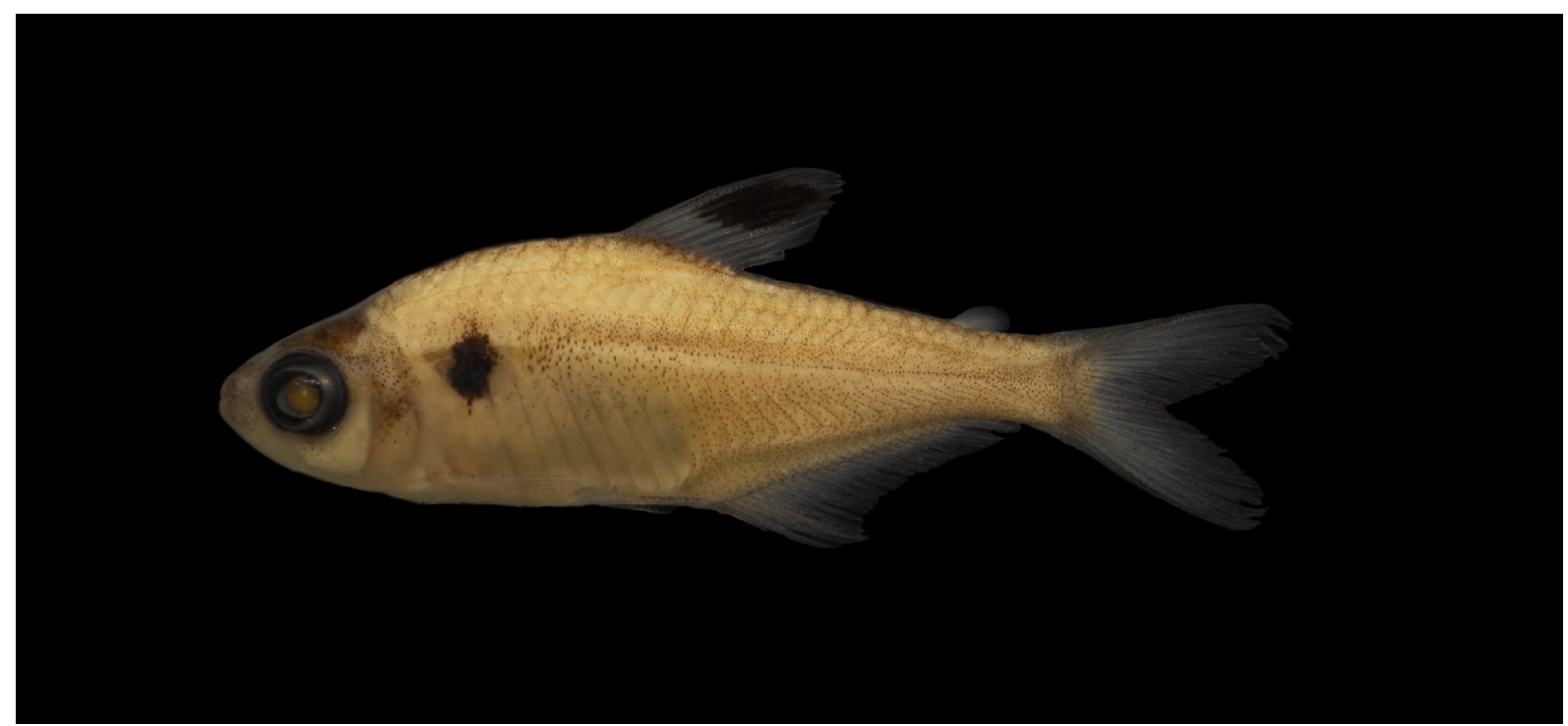

Fig. 4. Hyphessobrycon geryi Guimarães, Brito, Bragança, Katz \& Ottoni sp. nov., holotype (CICCAA 02403), 28.3 mm SL; Brazil: Maranhão State: Lower Tocantins River basin.

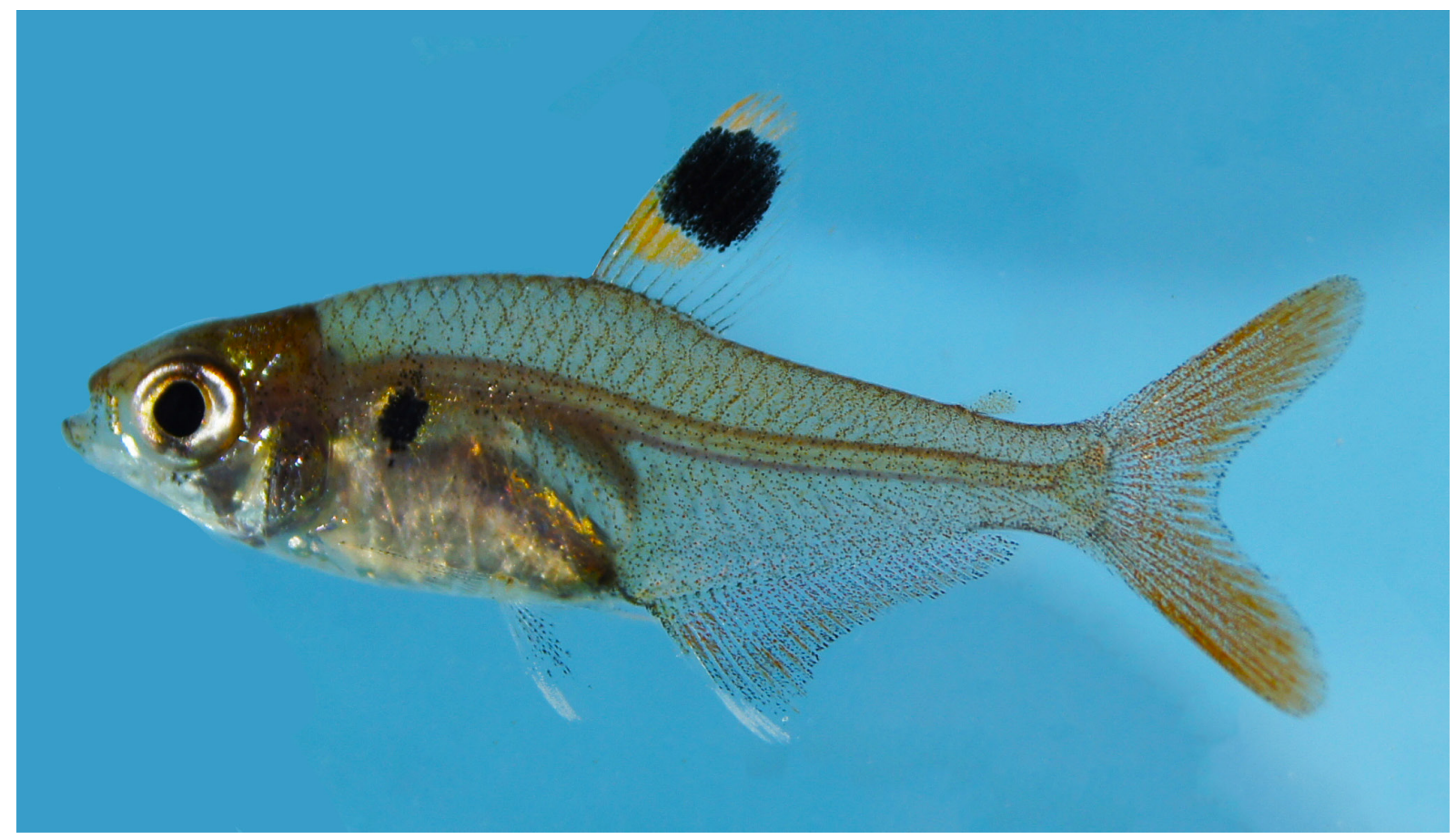

Fig. 5. Hyphessobrycon geryi Guimarães, Brito, Bragança, Katz \& Ottoni sp. nov., paratype (CICCAA 02348), $22.7 \mathrm{~mm} \mathrm{SL}$; Brazil: Maranhão State: Lower Tocantins River basin; living specimen photographed immediately after collection. 


\section{Material examined}

Holotype

BRAZIL • $27.8 \mathrm{~mm}$ SL; Pará State, Marabá municipality, Flexeiras River, Tocantins River basin; 5¹5'38" S, 48 59'35" W; 20 Sep. 2016; E.C. Guimarães and C.H. Costa; CICCAA 02403

\section{Paratypes}

BRAZIL - Pará State 1 spec.; $25.6 \mathrm{~mm}$ SL; same collection data as for holotype; CICCAA 00722 - 13 specs; 15.9-19.5 mm SL; Marabá municipality, Flexeiras River, Tocantins River basin; 5¹5'38" S, 4859'35" W; 21 Sep. 2018; E.C. Guimarães and P.S. Brito leg.; CICCAA 02358 • 11 specs; 16.9-19.2

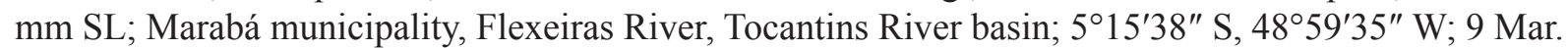
2018; E.C. Guimarães and P.S. Brito leg.; CICCAA 02359 • 11 specs; $18.8-22.2$ mm SL; Bom Jesus do Tocantis, Jacundá River, Tocantins River basin; 5 ${ }^{\circ} 15^{\prime} 1^{\prime \prime} \mathrm{S}, 48^{\circ} 48^{\prime} 58^{\prime \prime}$ W; 21 Dec. 2017; E.C. Guimarães and P.S. Brito leg.; CICCAA 02167 • 1 spec.; 23.6 mm SL; Bom Jesus do Tocantis, Jacundá River, Tocantins River basin; 5 $15^{\prime} 1^{\prime \prime}$ S, 48 48'58" W; 21 Aug. 2017; E.C. Guimarães and P.S. Brito leg.; CICCAA $2348 \cdot 5$ specs; 21.1-23.1 mm SL (C\&S); Marabá municipality, Flexeiras River, Tocantins River basin; 5¹5'38' S, 48 59'35" W; 21 Aug. 2017; E.C. Guimarães and P.S. Brito leg.; CICCAA 04800 • 1 spec.; 17.9 mm SL; Bom Jesus do Tocantins, Jacundá River, Tocantins River basin; $5^{\circ} 15^{\prime} 1^{\prime \prime} \mathrm{S}$, 48 48'58" W; 21 Sep. 2018; E.C. Guimarães and P.S. Brito leg.; UFRJ 6919 • 4 specs; 16.3-19.2 mm SL; Marabá municipality, Tocantins River basin; $5^{\circ} 15^{\prime} 38^{\prime \prime}$ S, 48 59'35" W; 10 Jul. 2017; E.C. Guimarães and P.S. Brito leg.; CICCAA 01839 • 5 specs; 18.0-18.9 mm SL (C\&S); Marabá municipality, Tocantins River basin; 515'38' S, 48 59'35" W; 21 Sep. 2018; E.C. Guimarães and P.S. Brito leg.; CICCAA 02402 - Maranhão State • 1 spec.; 26.1 mm SL; Igarapé Papagaio, Tocantins River basin; 58'59" S, 48²2'33" W; 20 Jan. 2014; E.C. Guimarães leg.; CICCAA 01958.

\section{Type locality}

Brazil, Pará State, Marabá municipality, Flexeiras River, Tocantins River basin, $5^{\circ} 15^{\prime} 38^{\prime \prime} \mathrm{S}, 48^{\circ} 59^{\prime} 35^{\prime \prime} \mathrm{W}$ (Fig. 3).

\section{Description}

Morphometric data of holotype and paratypes are presented in Table 3.

Body. Small (with maximum SL of $23.6 \mathrm{~mm}$ ), compressed, moderately deep, greatest body depth slightly anterior to dorsal-fin base; body profile straight and downward directed from end of dorsal fin to adipose fin, straight or slightly convex between latter point and origin of dorsal most procurrent caudal-fin ray; dorsal profile of head convex from upper lip to vertical through eye; predorsal profile of body roughly straight, dorsal-fin base slightly convex, posteroventrally inclined; ventral profile of head convex from lower jaw to pelvic-fin origin; straight and posterodorsally slanted along anal-fin base; and slightly concave on caudal peduncle; jaws equal, mouth terminal. Maxilla reaching vertical to anterior margin of pupil.

Teeth. Premaxillary teeth in two rows. Outer row with two tricuspid teeth; inner row with 5(2), 6(3) tricuspid teeth. Maxilla with 2(2), 3(2) or 4(1) pentacuspid teeth. Dentary with five (3) or six (2) larger tricuspid teeth followed by five (4) or six (1) smaller pentacuspid tooth (Fig. 6).

SCALES. Scales cycloid, three to eight radii strongly marked, circuli well-marked anteriorly, weaklymarked posteriorly; lateral line incompletely pored, with $7(31) *$ or $8(21)$ perforated scales. Longitudinal scales series including lateral-line scales 34(4), 35(2), 36(43)* or 37(1). Longitudinal scales rows between dorsal-fin origin and lateral line 5(46) or 6(4). Horizontal scale rows between lateral line and pelvic-fin origin 4(50) or 5(2). Scales in median series between tip of supraoccipital spine and dorsal-fin origin $9(35)$ or 10(15). Circumpeduncular scales 12(52). 
Fins. Dorsal-fin origin at midbody. Base of last dorsal-fin ray at vertical through first third of anal fin. Dorsal-fin rays ii $+9(50)^{*}$ or iii $+9(2)$. First dorsal-fin pterygiophore main body located behind neural spine of $4^{\text {th }}$ vertebrae. Adipose fin present. Anal-fin origin aligned with vertical line through middle of dorsal fin, between $6^{\text {th }}$ and $8^{\text {th }}$ dorsal-fin rays. Anteriormost anal-fin pterygiophore inserting posterior to haemal spine of $11^{\text {th }}$ vertebrae. Anal-fin origin aligned with vertical line through middle of dorsal fin (between base of $6^{\text {th }}$ and $8^{\text {th }}$ dorsal-fin rays). Anal fin iii $+22(40) *$ or iii $+23(12)$; Anterior anal-fin margin slightly convex, with anteriormost rays more elongate and slightly more thickened than remaining rays, forming a distinct lobe. Remaining rays smaller with straight distal margin. Pectoral-fin rays 12(52) total rays. Tip of pectoral fin surpassing pelvic-fin base. Pelvic-fin rays 8(52) total rays, surpassing anal-fin origin. Caudal fin forked, upper and lower lobes similar in size. Principal caudal-fin rays $11+10(30)$ or $10+9(22)$; dorsal procurrent rays $8(8)$ or $9(2)$ and ventral procurrent rays $7(3)$ or $8(7)$.

Osteological counts. Branchiostegal rays 10(10). First gill arch with 1(8), 2(2) hypobranchial, 11(2), 12(8) ceratobranchial, 1(10) cartilage between ceratobranchial and epibranchial, and 5(2) or 6(8) epibranchial gill-rakers. Supraneurals 4(8) or 5(2). Precaudal vertebrae 11 (10) and caudal vertebrae 19 (10). Total vertebrae 30(10).

\section{Coloration in alcohol (Fig. 4)}

Ground coloration light yellowish brown. Humeral spot conspicuous, slightly vertically elliptical, with a thin vertical line, formed by the concentration of dark chromatophores, at middle of humeral spot, extending one to two scales above and below humeral spot. Flank with conspicuous chromatophores scattered mainly on middle region, from just after humeral spot, reaching caudal peduncle end. Ventral region lacking dark brown chromatophores. Dark brown chromatophores present on head,
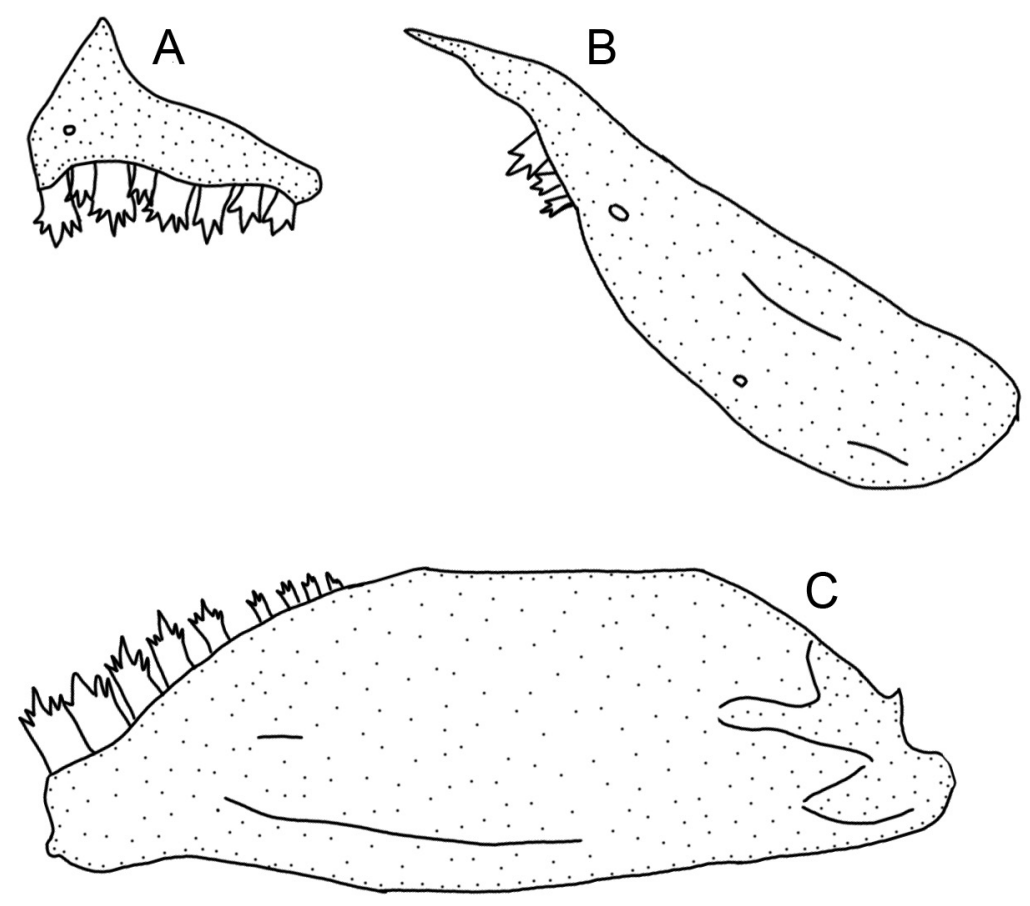

Fig. 6. Hyphessobrycon geryi Guimarães, Brito, Bragança, Katz \& Ottoni sp. nov. (CICCAA 02402), $23.2 \mathrm{~mm}$ SL. Jaw suspensory. A. Premaxillary. B. Maxilla. C. Dentary. Scale bar: $1 \mathrm{~mm}$ 
more concentrated on dorsal portion, tip of snout, and opercular region, becoming sparser on cheek. Dorsal-fin ground coloration hyaline, with conspicuous black or dark brown spot located on anterior portion of fin, reaching about $6^{\text {th }}$ ray, approximately between half to two thirds of fin depth. Conspicuous pigmentation on dorsal-fin base formed by concentration of conspicuous chromatophores. Anal and caudal fins hyaline. Anal and caudal fin with darker, usually dark brown, posterior margin. Adipose fin hyaline to light brown, with dark chromatophores at margin and posterior portion. Pectoral and pelvic fins hyaline; pelvic fin with variable amounts of dark brown pigmentation remaining depending on specimen preservation state.

\section{Color in life (Fig. 5)}

Color pattern similar to coloration of preserved specimens, with more translucent body. Ground coloration translucent, white to grey, with orange pigmentation on vertebrae region, and usually with orange chromatophores. Ventral region anterior to anal-fin origin lighter.

Chromatophores on humeral region black. Head darker than flank, especially on opercular and dorsal regions; ventrally lighter. Conspicuous black spot on dorsal fin, with yellow or white pigmentation on dorsal and ventral margins of spot; rest of dorsal fin hyaline. Anal fin base with light red chromatophores, with different degrees of intensity, with milk white pigmentation on anterior tip of anal fin, reaching between first to second rays. Adipose fin hyaline, with light red chromatophores mainly at base, and black chromatophores at margin. Pectoral and pelvic fins hyaline, with some sparser dark brown chromatophores, more concentrated at pelvic fin, and with milk white pigmentation on anterior tip of pelvic fin. Caudal fin with red pigmentation on almost fin, with inconspicuous light brown margin.

\section{Sexual dimorphism}

Bony hooks on fins is absent in all examined specimens. According to Malabarba \& Weitzman (2003) the presence of bony hooks is a common dimorphic feature among characids species. Although this sexual dimorphism is not observed in all characid species, as in case of species described here. Color pattern is not sexually dimorphic either.

\section{Species delimitation}

\section{WP and CBB}

The BI phylogenetic analysis supported a clade comprising Hyphessobrycon geryi Guimarães, Brito, Bragança, Katz \& Ottoni sp. nov., H. copelandi, H. frickei Guimarães, Brito, Bragança, Katz \& Ottoni sp. nov. and $H$. aff. copelandi, hereafter termed Hyphessobrycon copelandi clade, with maximum posterior probability value (posterior probability $=1$ ). Hyphessobrycon frickei $\mathrm{sp}$. nov. and $H$. geryi sp. nov. haplotypes formed two exclusive clades with maximum posterior probability value (posterior probability $=1$ ), as well as $H$. copelandi and $H$. aff. copelandi. The nucleotide substitutions supporting these lineages within the H. copelandi clade are presented in Fig. 7 and Appendix 2. The combination of nucleotide substitutions diagnosing $H$. frickei sp. nov. and $H$. geryi sp. nov. are presented in the molecular diagnosis section.

\section{DBC}

The alignment comprised a total of 26 haplotypes. After trimming, the final alignment yielded 639 base pairs with 159 polymorphic sites. Average genetic distances were $17 \%$, with the highest values between $H$. epicharis and H. erythrostigma (23.4\%), while the lowest value of $(0.08 \%)$ was between $H$. pyrrhonotus and $H$. erythrostigma (Table 3). Hyphessobrycon frickei sp. nov. and $H$. geryi sp. nov. are divergent on average $17 \%$, from the other taxa, with a minimum distance of $3.5 \%$ and $4.4 \%$, respectively, to $H$. copelandi, and $4.7 \%$ of divergence between them (Table 4), thus both species being recovered by this genetic distance method. 


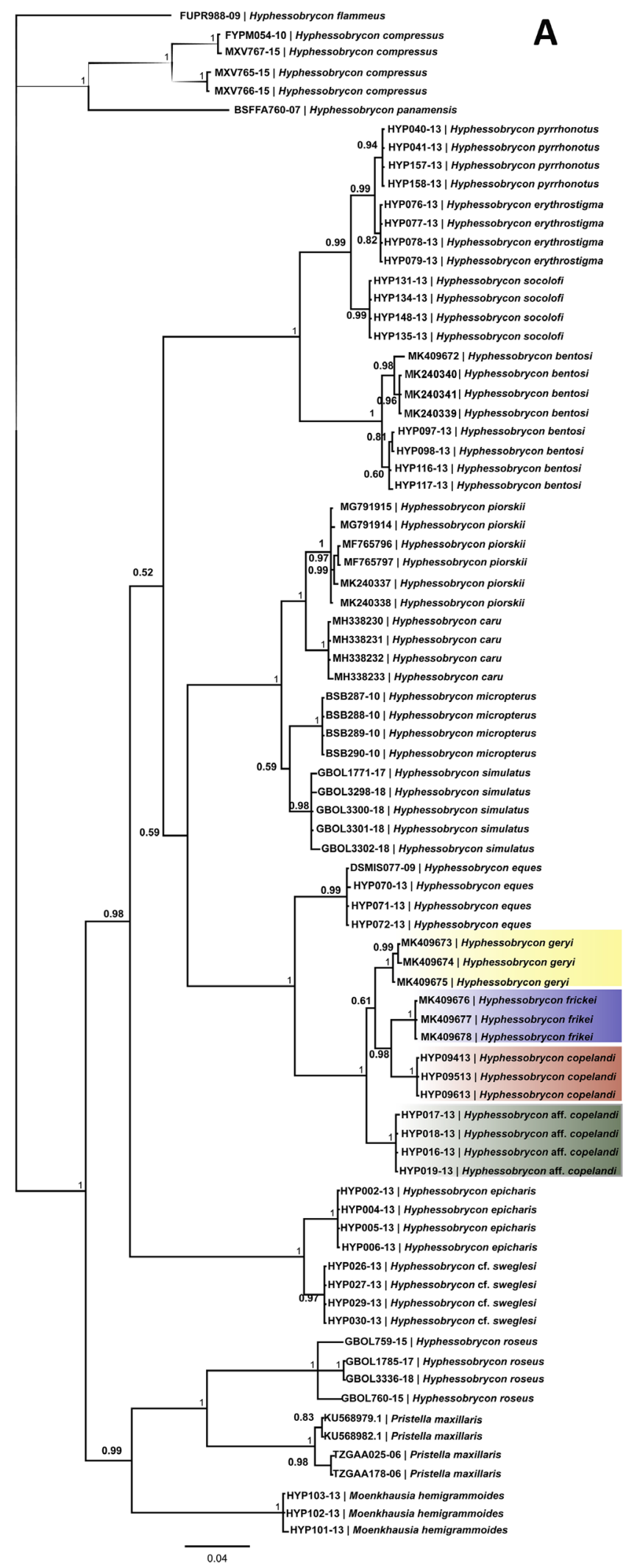

B

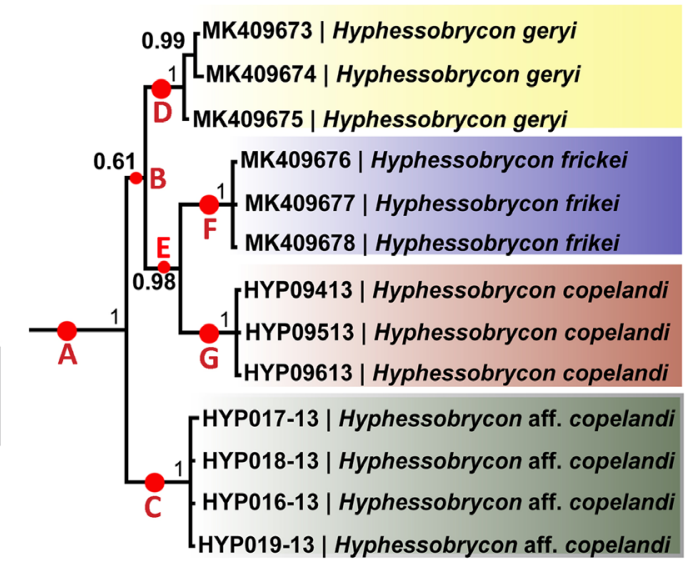

Fig. 7. A. Bayesian Inference phylogenetic tree (BI). B. Detached relationships between members of the of the Hyphessobrycon copelandi clade. Numbers above and below branches are posterior probability values, and red letters correspond to synapomorphic nucleotide substitutions listed in Appendix 2. 


\title{
GMYC and bPTP
}

Both unilocus coalescent species delimitation methods delimited the same eight lineages (species): $H$. caru, H. piorskii, $H$. geryi sp. nov., H. copelandi, H. frickei sp. nov. and $H$. aff. copelandi; in addition to the species included as outgroup, H. bentosi, that was split into two distinct lineages (Fig. 8).

\begin{abstract}
ABDG
In the ABDG species delimitation method, the same ingroup taxa as delimited in the coalescent species delimitation methods have been defined comprising: H. caru, H. piorskii, H. geryi sp. nov., H. copelandi, $H$. frickei $\mathrm{sp}$. nov. and $H$. aff. copelandi. In constrast to the coalescent methods results, all haplotypes from $H$. bentosi, the outgroup taxa, were recognized as a single species. The same seven groups (species) were delimited between $\mathrm{P}$ values ranging from 0.0017 and 0.0215 (Fig. 8).
\end{abstract}

\section{Discussion}

Recent DNA-based studies suggest that tropical faunas contain a large proportion of undescribed species (e.g., Roca et al. 2001; Hrbek et al. 2014; Poulakakis et al. 2015; Murphy et al. 2016; Bittencourt et al. 2019; Guimarães et al. 2018, 2019; de Brito et al. 2019). This fact is more evident in freshwater fishes, since freshwater systems are isolated, hampering the migration of species from one river system into another. Such a situation favors speciation, in many cases resulting in cryptic species, which is common among Neotropical fish lineages, as evidenced and revealed by work dealing with species delimitation molecular approaches (e.g., Costa \& Amorim 2011; Costa et al. 2012, 2014, 2017; Pereira et al. 2011; Benzaquem et al. 2015; Melo et al. 2014, 2016a, 2016b, 2016c; Amorim 2018; Mattos \& Costa 2018; Carvalho et al. 2018; Guimarães et al. 2018, 2019; Rosso et al. 2018; Ottoni et al. 2019; de Santana et al. 2019). Recently, the presence of cryptic species and a greater biodiversity have been also evidenced for the "Rosy tetra" clade (e.g., Castro-Paz et al. 2014; Guimarães et al. 2018, 2019), which is herein corroborated, with the description of two new species belonging to this clade, based on seven different species delimitations methods.

In the present research, we suggest a new clade within the "Rosy tetra", the Hyphessobrycon copelandi clade, comprising four species: Hyphessobrycon copelandi, with its type locality at Tabatinga, Amazonas, Brazil, close to the border with Peru and Colombia (Eigenmann 1908); the two new species herein described, Hyphessobrycon frickei Guimarães, Brito, Bragança, Katz \& Ottoni sp. nov. and H. geryi Guimarães, Brito, Bragança, Katz \& Ottoni sp. nov. from the Maracaçumé River basin in northeastern Brazil and the middle Tocantins River basin in east Amazon, Brazil, respectively; and an undescribed species from the lower Rio Negro basin (here called $H$. aff. copelandi). The Hyphessobrycon copelandi clade was corroborated by maximum node support (see Fig. 7), as well as, by 25 synapomorphic nucleotide substitutions (see Fig. 7 and Appendix 2).

Hyphessobrycon frickei sp. nov. and $H$. geryi sp. nov. were identified as new species by seven different and independent methods of species delimitation (PAA, DBC, WP, CBB, bPTP, GMYC and ABGD), relying on different sources of characters (morphology and DNA), different criteria and assumptions; under an Integrative Taxonomy perspective (Sytsma \& Schaal 1985; Dayrat 2005; Goldstein \& Desalle 2010; Padial et al. 2010). Both species are distinguished from all their congeners mainly by the arrangement, shape and color pattern of the humeral and dorsal-fin spots, as well as by other characters related to scale counts and body pigmentation (see PAA - Diagnosis). In our bayesian inference phylogenetic analysis (Fig. 7), haplotypes belonging to both species formed two exclusive clades with maximum posterior probability value (posterior probability $=1)(\mathrm{WP})$, as well as, the other two species within the Hyphessobrycon copelandi clade. Furthermore, the minimum COI genetic distance (DBC) of Hyphessobrycon frickei sp. nov. and $H$. geryi sp. nov. when compared to $H$. copelandi were $3.5 \%$ and $4.4 \%$, respectively, and $4.7 \%$ of divergence between them (see Table 4). Considering this value, 
Table 3. Morphometric data $(\mathrm{N}=53)$ for the holotype and paratypes of Hyphessobrycon geryi Guimarães, Brito, Bragança, Katz \& Ottoni sp. nov. SD = Standard deviation.

\begin{tabular}{lcccc}
\hline & Holotype & Paratypes & Mean & SD \\
\hline Standard length & 28.2 & $15.9-26.1$ & 19.7 & - \\
& Percentages of standard length & & & \\
Depth at dorsal-fin origin (body depth) & 32.4 & $27.7-34.4$ & 31.5 & 1.2 \\
Snout to dorsal-fin origin & 51.5 & $49.6-53.6$ & 51.5 & 0.8 \\
Snout to pectoral-fin origin & 25.7 & $26.4-29.7$ & 28.2 & 1.1 \\
Snout to pelvic-fin origin & 42.7 & $44.1-47.0$ & 45.1 & 0.8 \\
Snout to anal-fin origin & 57.2 & $53.4-63.4$ & 58.8 & 1.7 \\
Caudal peduncle depth & 9.8 & $7.0-11.3$ & 9.8 & 0.9 \\
Caudal peduncle length & 11.3 & $8.3-12.8$ & 10.2 & 1.0 \\
Pectoral-fin length & 19.2 & $14.8-22.18$ & 19.7 & 1.6 \\
Pelvic-fin length & 17.0 & $14.4-20.1$ & 16.2 & 1.4 \\
Dorsal-fin base length & 13.9 & $11.9-15.9$ & 14.4 & 0.8 \\
Dorsal-fin height & 25.5 & $23.5-33.0$ & 28.1 & 1.8 \\
Anal-fin base length & 31.3 & $30.2-34.6$ & 32.7 & 1.2 \\
Eye to dorsal-fin origin & 37.4 & $34.5-39.2$ & 36.7 & 0.9 \\
Dorsal-fin origin to caudal-fin base & 54.7 & $50.5-56.2$ & 53.7 & 1.1 \\
Head length & 27.6 & $26.9-29.8$ & 29.1 & 0.6 \\
& Percentages of head length & & & \\
Horizontal eye diameter & 36.8 & $36.8-46.1$ & 41.4 & 2.3 \\
Snout length & 20.9 & $19.5-26.3$ & 22.8 & 1.7 \\
Least interorbital width & 27.1 & $25.5-33.3$ & 28.8 & 1.1 \\
Upper jaw length & 32.4 & $30.2-37.7$ & 33.2 & 2.6 \\
\hline
\end{tabular}

Hyphessobrycon frickei sp. nov. and $H$. geryi sp. nov. genetic divergence is greater than that commonly inferred by species delimitations among Neotropical fish species $(2 \%)$ based on COI (Jacobina et al. 2018). Moreover, Hyphessobrycon frickei and $H$. geryi sp. nov. were also molecularly diagnosed by synapomorphic nucleotide substitutions, as well as by an accessory combination of other nucleotide substitutions (see CBB - molecular diagnosis sections, Fig. 7 and Appendix 2). At last, both coalescent species delimitation methods (GMYC and bPTP) corroborated these two new species, as well as, the Automatic Barcode Gap Discovery (ABGD) (Fig. 8). The same result found by all the methods applied here only reinforces the hypothesis that these species are in fact new to science.

Similar results from previous studies (e.g., Castro-Paz et al. 2014; Guimarães et al. 2018, 2019) agree with our hypothesis of the existence of cryptic species within the "Rosy tetra" clade, and also suggests that its species diversity is still underestimated. We would like to highlight the paper published by Guimarães et al. $(2018,2019)$ that also proposed and evidenced a new subclade within the "Rosy tetra" clade, the Hyphessobrycon micropterus clade, revealing the existence of cryptic species and a greater diversity than previously known within the group. 


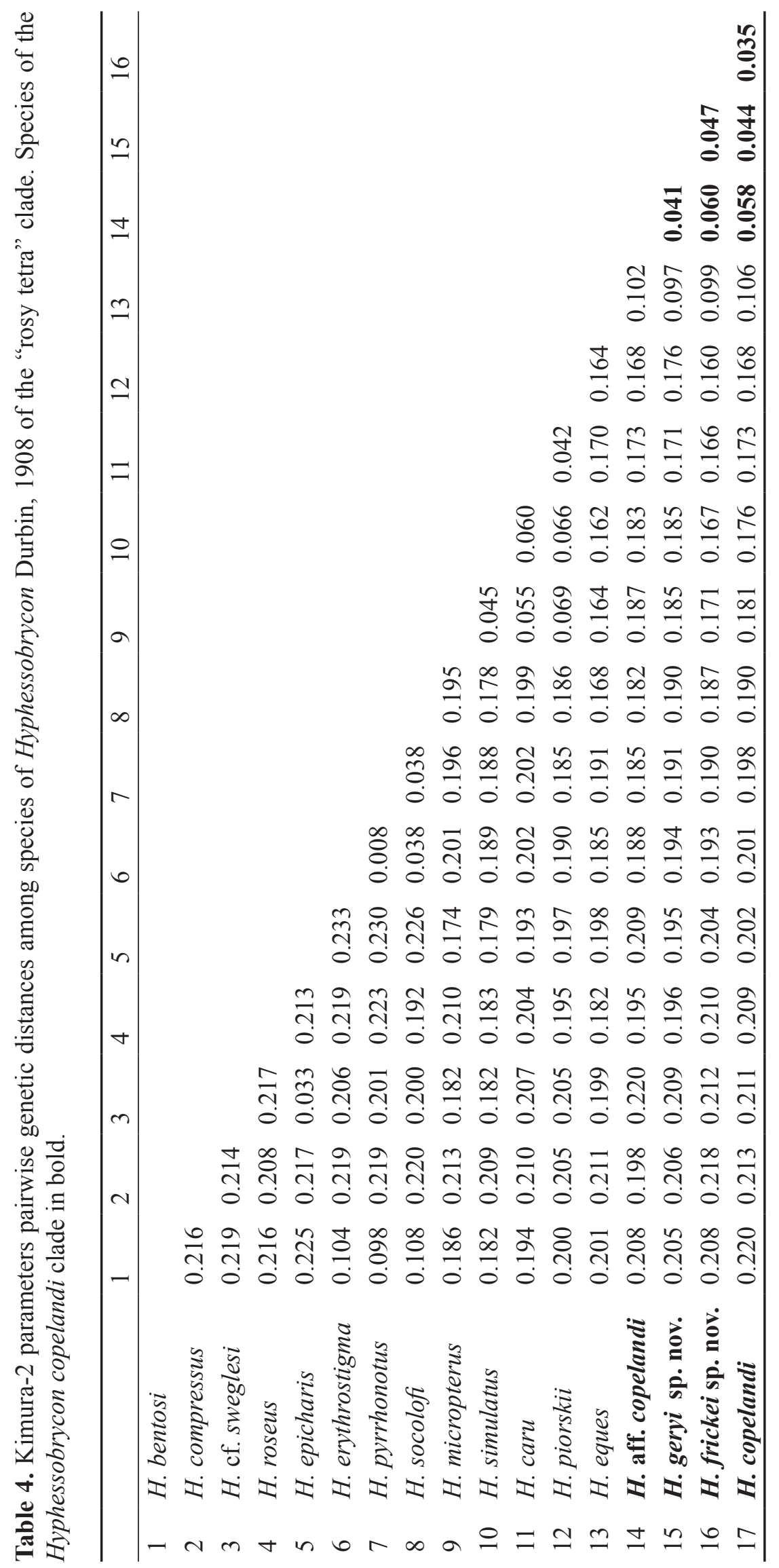




\section{Conclusion}

The present paper highlights the importance of a species delimitation through an integrative framework allowing to solve taxonomic and classification problems in Hyphessobrycon taxonomy, and estimating the diversity of this group with accuracy, being crucial for futures studies on phylogeny, phylogeography, ecology, conservation and biogeography. We consider that difficulties to recognize the boundaries at the species or genus levels can be overcome through the adoption of integrative studies and perspectives, dealing with multiple criteria and character sources to make taxonomic decisions.

\section{Acknowledgements}

Thanks are owed to A. Zarske, I. Schindler, O. Lasso-Alcalá and R. Fricke for providing useful literature; Vale S.A and Amplo Engenharia for the cession of part of the data analyzed in this study; Raphael Covain (MHNG) and collaborators of the Project Gui-BOL Barcoding Guianese fishes for the cession of part

GMYC bPTP ABGD

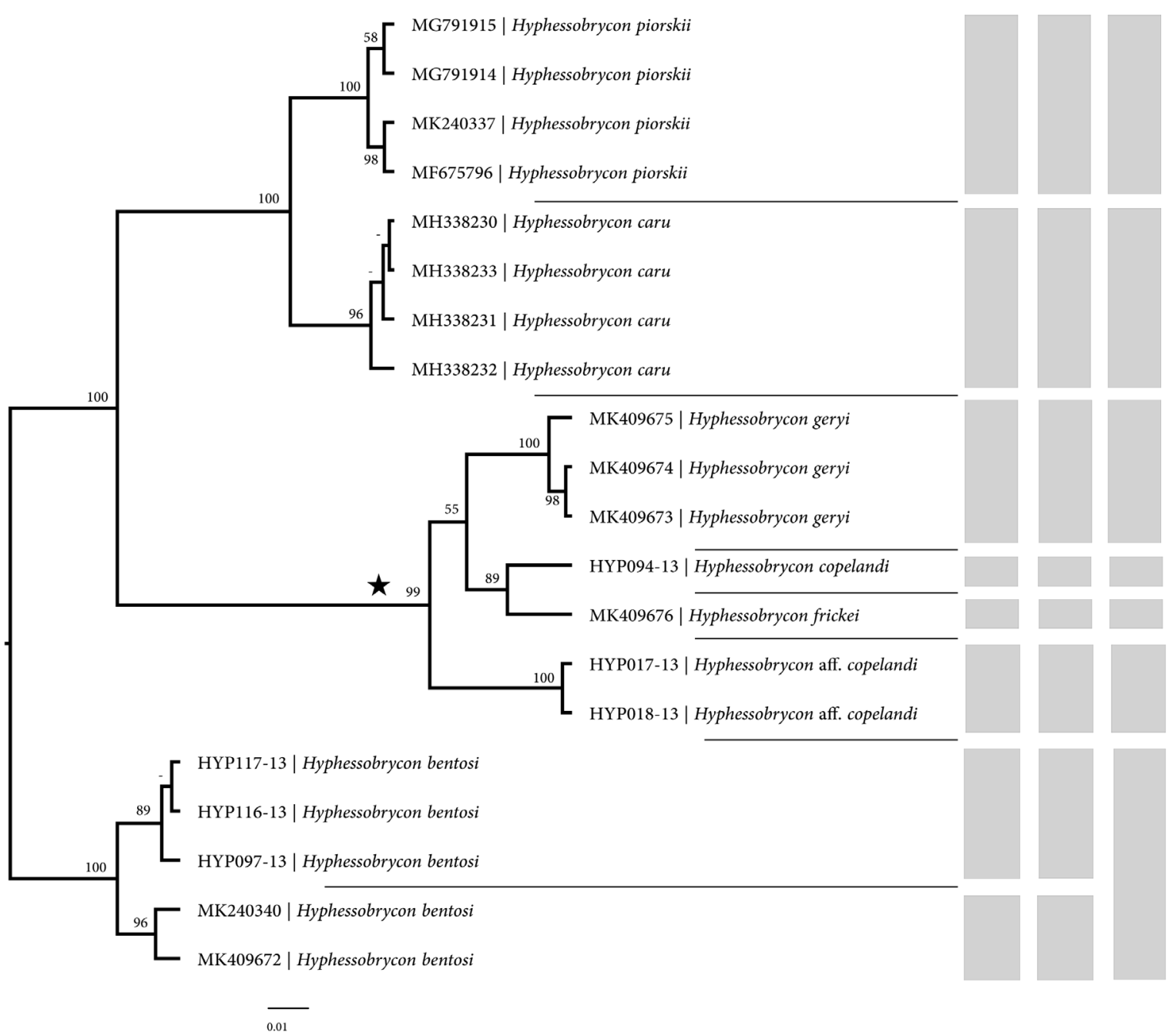

Fig. 8. Topology of the ultrametric tree performed in BEAST ver. 1.8.4 including unique haplotypes summarizing the results of GMYC, bPTP and ABGD. Numbers above and below branches are posterior probability values. The star indicates the Hyphessobrycon copelandi clade. 
of the data analyzed in this study; Wilson Costa (UFRJ) for the loan and donation of material; Andrew Williston (MCZ), James Maclaine and Kevin Swagel (BMNH), Mark Sabaj Pérez and Dave Catania (CAS), Riedel Bettina (NMW) and Sandra Raredon (USNM) for providing photographs, $x$-ray images, and information on the type material of some species; CAPES (Coordenação de Aperfeiçoamento de pessoal de nível Superior - Finance Code 001) and FAPEMA for providing the scholarship to PSB under the process 88887.159561/2017-00. All material was collected with permits 51540-3/ from SISBIO (Brazilian Institute of Environment and Natural Resources).

\section{References}

Alfaro M.E. \& Holder M.T. 2006. The posterior and the prior in Bayesian phylogenetics. Annual Review of Ecology, Evolution, and Systematics 37: 19-42.

https://doi.org/10.1146/annurev.ecolsys.37.091305.110021

Amorim F.P. 2018. Jenynsia lineata species complex, revision and new species description (Cyprinodontiformes: Anablepidae). Journal of Fish Biology 92: 1312-1332. https://doi.org/10.1111/jfb.13587

Avise J.C. 2000. Phylogeography: the History on Formation of Species. University Press, Cambridge.

Benine R.C., Melo B.F., Castro R.M.C. \& Oliveira C. 2015. Taxonomic revision and molecular phylogeny of Gymnocorymbus Eigenmann, 1908 (Teleostei, Characiformes, Characidae). Zootaxa 3956 (1): 1-28. https://doi.org/10.11646/zootaxa.3956.1.1

Betancur-R R., Arcila D., Vari R.P., Hughes L.C., Oliveira C., Sabaj M.H. \& Ortí G. 2018. Phylogenomic incongruence, hypothesis testing, and taxonomic sampling: The monophyly of characiform fishes. Evolution 73 (2): 329-345. https://doi.org/10.1111/evo.13649

Benzaquem D.C., Oliveira C., da Silva Batista J., Zuanon J. \& Porto J.I.R. 2015. DNA Barcoding in Pencilfishes (Lebiasinidae: Nannostomus) Reveals Cryptic Diversity across the Brazilian Amazon. PLoS ONE 10 (2): e0112217. https://doi.org/10.1371/journal.pone.0112217

Bickford D., Lohman D.J., Sodhi N.S., Ng P.K.L., Meier R., Winker K., Ingram K.K. \& Das I. 2006. Cryptic species as a window on diversity and conservation. Trends in Ecology and Evolution 22 (3): 148-155. https://doi.org/10.1016/j.tree.2006.11.004

Bittencourt P.S., Campos Z., Muniz F.L., Marioni B., Souza B.C., Da Silveira R., de Thoisy B., Hrbek T. \& Farias I.P. 2019. Evidence of cryptic lineages within a small South American crocodilian: the Schneider's dwarf caiman Paleosuchus trigonatus (Alligatoridae: Caimaninae). PeerJ 7: e6580. https://doi.org/10.7717/peerj.6580

Bragança P.H.N., Ottoni F.P. \& Rangel-Pereira F.S. 2015. Hyphessobrycon ellisae, a new species from northeastern Brazil (Teleostei: Characidae). Ichthyological Exploration of Freshwaters 26 (3): 255-262.

de Brito P.S., Guimarães E.C., Carvalho-Costa L.F. \& Ottoni F.P. 2019. A new species of Aphyocharax Günther, 1868 (Characiformes, Characidae) from the Maracaçumé river basin, eastern Amazon. Zoosystematics and Evolution 95 (2): 507-516. https://doi.org/10.3897/zse.95.36788

Carvalho F.R. \& Malabarba L.R. 2015. Redescription and osteology of Hyphessobrycon compressus (Meek) (Teleostei: Characidae), type species of the genus. Neotropical Ichthyology 13 (3): 513-540. https://doi.org/10.1590/1982-0224-20140173

Carvalho M.L., Costa Silva G.J,. Melo S., Ashikaga F.Y., Shimabukuro-Dias C.K., Scacchetti P.C., Devidé R., Foresti F. \& Oliveira C. 2018. The non-monotypic status of the neotropical fish genus Hemiodontichthys (Siluriformes, Loricariidae) evidenced by genetic approaches. Mitochondrial DNA Part A 29 (8): 1224-1230. https://doi.org/10.1080/24701394.2018.1431230 
Castro-Paz F.P., Batista J.S. \& Porto J.I.R. 2014. DNA Barcodes of Rosy Tetras and Allied Species (Characiformes: Characidae: Hyphessobrycon) from the Brazilian Amazon Basin. PLoS ONE 9 (5): e98603. https://doi.org/10.1371/journal.pone.0098603

Chenna R., Sugawara H., Koike T., Lopez R., Gibson T.J., Higgins D.G. \& Thompson J.D. 2003. Multiple sequence alignment with the Clustal series of programs. Nucleic Acids Research 31: $3497-$ 3500. https://doi.org/10.1093/nar/gkg500

Close B., Banister K., Baumans V., Bernoth E.M., Bromage N., Bunyan J., Erhardt W., Flecknell P., Gregory N., Hackbarth H. \& Morton D. 1996. Recommendations for euthanasia of experimental animals: Part 1. Laboratory Animals 30 (4): 293e316. https://doi.org/10.1258/002367796780739871

Close, B., Banister, K., Baumans, V., Bernoth, E.M., Bromage, N., Bunyan, J., Erhardt, W., Flecknell, P., Gregory, N., Hackbarth, H. \& Morton, D. 1997. Recommendations for euthanasia of experimental animals: Part 2.Laboratory Animals 31 (1): 1e32. https://doi.org/10.1258/002367797780600297

Costa W.J.E.M. \& Amorim P.F. 2011. A new annual killifish species of the Hypsolebias flavicaudatus complex from the São Francisco River basin, Brazilian Caatinga (Cyprinodontiformes: Rivulidae). Vertebrate Zoology 61 (1): 99-104.

Costa W.J.E.M., Amorim P.F. \& Mattos J.L.O. 2012. Species delimitation in annual killifishes from the Brazilian Caatinga, the Hypsolebias flavicaudatus complex (Cyprinodontiformes: Rivulidae): implications for taxonomy and conservation. Systematics and Biodiversity 10: 71-91.

https://doi.org/10.1080/14772000.2012.664177

Costa W.J.E.M., Amorim P.F. \& Aranha G.N. 2014. Species limits and DNA barcodes in Nematolebias, a genus of seasonal killifishes threatened with extinction from the Atlantic Forest of south-eastern Brazil, with description of a new species (Teleostei: Rivulidae). Ichthyological Exploration of Freshwaters 24 (3): 225-236.

Costa W.J.E.M., Cheffe M.M. \& Amorim P.F. 2017. Two new seasonal killifishes of the Austrolebias adloffi group from the Lagoa dos Patos basin, southern Brazil (Cyprinodontiformes: Aplocheilidae). Vertebrate Zoology 67 (2): 139-149.

Darriba D., Taboada G.L., Doallo R. \& Posada D. 2012. jModelTest 2: more models, new heuristics and parallel computing. Nature Method 9 (8): 772. https://doi.org/10.1038/nmeth.2109

Davis J.I. \& Nixon K.C. 1992. Populations, genetic variation, and the delimitation of phylogenetics species. Systematic Biology 41 (4): 421-435. https://doi.org/10.1093/sysbio/41.4.421

Dayrat B. 2005. Towards integrative taxonomy. Biological Journal of the Linnean Society 85 (3): $407-$ 415. https://doi.org/10.1111/j.1095-8312.2005.00503.x

Desalle R., Egan M.G. \& Siddall M. 2005. The unholy trinity: taxonomy, species delimitation and DNA barcoding. Philophical Transactions of the Royal Society B 360: 1905-1916.

https://doi.org/10.1098/rstb.2005.1722

Drummond A.J., Suchard M.A., Xie D. \& Rambaut A. 2012. Bayesian phylogenetics with BEAUti and the BEAST 1.7. Molecular Biology and Evolution 29: 1969-1973.

Eigenmann C.H. 1908. Preliminary descriptions of new genera and species of Tetragonopterid characins. Bulletin of the Museum of Comparative Zoology 52: 91-106.

Eigenmann C.H. 1918. The American Characidae (Part 2). Memoirs of the Museum of Comparative Zoology 43: 101-208.

Fink W. \& Weitzman S. 1974. The so called cheirodontin fishes of Central America with descriptions of two new species (Pisces: Characidae). Smithsonian Contributions to Zoology 172: 1-45. 
https://doi.org/10.5479/si.00810282.172

Fricke R. \& Eschmeyer W.N. 2020. Guide to fish collections.

Available from http://researcharchive.calacademy.org/research/ichthyology/catalog/collections.asp [accessed 10 Mar. 2020].

Fricke R., Eschmeyer W.N. \& van der Laan R. 2020a. Catalog of Fishes: Genera, Species, References. Available from http://researcharchive.calacademy.org [accessed 31 Mar. 2020].

Fricke R., Eschmeyer W.N. \& Jon D.F. 2020b. Catalog of Fishes: Species by Family/Subfamily. Available from http://researcharchive.calacademy.org/research/ichthyology/catalog/SpeciesByFamily.asp [accessed 31 Mar. 2020].

Fujisawa T. \& Barraclough T.G. 2013. Delimiting species using single-locus data and the Generalized Mixed Yule Coalescent approach: a revised method and evaluation on simulated datasets. Systematic Biology 62 (5): 707-724. https://doi.org/10.1093/sysbio/syt033

García-Alzate C.A., Román-Valencia C. \& Taphorn D.C. 2008. Revision of the Hyphessobrycon heterorhabdus-group (Teleostei: Characiformes: Characidae), with description of two new species from Venezuela. Vertebrate Zoology 58 (2): 139-157.

García-Melo J.E., Oliveira C., Da Costa Silva G.J., Ochoa-Orrego L.E., Garcia Pereira L.H. \& MaldonadoOcampo J.A. 2019. Species delimitation of neotropical Characins (Stevardiinae): Implications for taxonomy of complex groups. PLoS ONE 14 (6): e 0216786.

https://doi.org/10.1371/journal.pone.0216786

Géry J. 1977. Characoids of the World. TFH-publications, Neptune City Inc.

Goldstein P.Z. \& Desalle R. 2010. Integrating DNA barcode data and taxonomic practice: determination, discovery, and description. BioEssays 33 (2): 135-147. https://doi.org/10.1002/bies.201000036

Guimarães E.C., De Brito P.S., Feitosa L.M., Carvalho-Costa L.F. \& Ottoni F.P. 2018. A new species of Hyphessobrycon Durbin from northeastern Brazil: evidence from morphological data and DNA barcoding (Characiformes, Characidae). ZooKeys 765: 79-101. https://doi.org/10.3897/zookeys.765.23157

Guimarães E.C., De Brito P.S., Feitosa L.M., Carvalho-Costa L.F. \& Ottoni F P. 2019. A new cryptic species of Hyphessobrycon Durbin, 1908 (Characiformes, Characidae) from the Eastern Amazon, revealed by integrative taxonomy. Zoosystematics and Evolution 95 (2): 345-360.

https://doi.org/10.3897/zse.95.34069

Hebert P.D.N., Cywinska A., Ball S.L. \& de Waard J.R. 2003a. Biological identifications through DNA barcodes. Proceedingsofthe Royal SocietyB270(1512):313-321.https://doi.org/10.1098/rspb.2002.2218

Hebert P.D.N., Ratnasingham S. \& de Waard J.R. 2003b. Barcoding animal life: cytochrome c oxidase subunit 1 divergences among closely related species. Proceedings of the Royal Society B 270 (1): 96-99. https://doi.org/10.1098/rsbl.2003.0025

Hebert P.D.N., Penton E.H., Burns J.M., Janzen D.H. \& Hallwachs W. 2004a. Ten species in one: DNA barcoding reveals cryptic species in the neotropical skipper butterfly Astraptes fulgerator. Proceedings of the National Academy of Sciences 101 (41): 14812-14817. https://doi.org/10.1073/pnas.0406166101

Hebert P.D.N., Stoeckle M.Y., Zemlak T.S. \& Francis C.M. 2004b. Identification of birds through DNA barcodes. PLoS Biology 2 (10): e312. https://doi.org/10.1371/journal.pbio.0020312

Hrbek T., Da Silva V.M.F., Dutra N., Gravena W., Martin A.R. \& Farias I.P. 2014. A new species of river dolphin from Brazil or: How little do we know our biodiversity. PLoS ONE 9 (1): e83623.

https://doi.org/10.1371/journal.pone.0083623 
Huelsenbeck J.P. \& Ronquist F. 2001. Mr. Bayes: Bayesian inference of phylogenetic trees. Bioinformatics 17 (8): 754-755. https://doi.org/10.1093/bioinformatics/17.8.754

Jacobina U.P., Lima S.M.Q., Maia D.G., Souza G., Batalha-Filho H. \& Torres R.A. 2018. DNA barcode sheds light on systematics and evolution of neotropical freshwater trahiras. Genetica 146 (6): 505-515. https://doi.org/10.1007/s10709-018-0043-x

Javonillo R., Malabarba L.R., Weitzman S.H. \& J.R. Burns. 2010. Relationships among major lineages of characid fishes (Teleostei: Ostariophysi: Characiformes), based on molecular sequence data. Molecular Phylogenetics and Evolution 54 (2): 498-511. https://doi.org/10.1016/j.ympev.2009.08.026

Kimura M. 1980. A simple method for estimating evolutionary rates of base substitutions through comparative studies of nucleotide sequences. Journal of Molecular Evolution 16 (2): 111-120.

https://doi.org/10.1007/BF01731581

Kumar S., Stecher G. \& Tamura K. 2016. MEGA7: Molecular evolutionary genetics analysis version 7.0 for bigger datasets. Molecular Biology and Evolution 33: 1870-1874.

https://doi.org/10.1093/molbev/msw054

Leary S., Underwood W., Anthony R., Cartner S., Corey D. \& Grandin T. 2013. AVMA Guidelines for the Euthanasia of Animals. Available from: http://works.bepress. com/cheryl_greenacre/14 [accessed 31 Mar. 2020].

Malabarba L. R. \& Weitzman S. H. 2003. Description of a new genus with six new species from Southern Brazil, Uruguay and Argentina, with a discussion of a putative characid clade (Teleostei: Characiformes: Characidae). Comunicações do Museu de Ciências e Tecnologia, PUCRS, Série Zoologia 16 (1): 67151.

Mattos J.L.O. \& Costa W.J.E.M. 2018. Three new species of the 'Geophagus' brasiliensis species group from the northeast Brazil (Cichlidae, Geophagini). Zoosystematics and Evolution 94 (2): 325-337. https://doi.org/10.3897/zse.94.22685

Melo B.F., Sidlauskas B.L., Hoekzema K., Vari R.P. \& Oliveira C. 2014. The first molecular phylogeny of Chilodontidae (Teleostei: Ostariophysi: Characiformes) reveals cryptic biodiversity and taxonomic uncertainty. Molecular Phylogenetics and Evolution 70: 286-295.

https://doi.org/10.1016/j.ympev.2013.09.025

Melo B.F., Ochoa L.E., Vari R.P. \& Oliveira C. 2016a. Cryptic species in the Neotropical fish genus Curimatopsis (Teleostei, Characiformes). Zoologica Scripta 45: 650-658.

https://doi.org/10.1111/zsc. 12178

Melo B.F., Sidlauskas B.L., Hoekzema K., Frable B.W., Vari R.P. \& Oliveira C. 2016b. Molecular phylogenetics of the Neotropical fish family Prochilodontidae (Teleostei: Characiformes). Molecular Phylogenetics and Evolution 102: 189-201. https://doi.org/10.1016/j.ympev.2016.05.037

Melo B.F., Benine R.C., Silva G.S.C., Avelino G.S. \& Oliveira C. 2016c. Molecular phylogeny of the Neotropical fish genus Tetragonopterus (Teleostei: Characiformes: Characidae). Molecular Phylogenetics and Evolution 94: 709-717. https://doi.org/10.1016/j.ympev.2015.10.022

Mirande J.M. 2010. Phylogeny of the family Characidae (Teleostei: Characiformes): from characters to taxonomy. Neotropical Ichthyology 8 (3): 385-568. https://doi.org/10.1590/S1679-62252010000300001

Mirande J.M. 2018. Morphology, molecules and the phylogeny of Characidae (Teleostei, Characiformes). Cladistics 1-19. https://doi.org/10.1111/cla.12345

Murphy J.C., Jowers M.J., Lehtinen R.M., Charles S.P., Colli G.R., Peres Jr.A.K., Hendry C.R. \& Pyron R.A. 2016. Cryptic, sympatric diversity in tegu lizards of the Tupinambis teguixin group (Squamata, Sauria, Teiidae) and the description of three new species. PLoS ONE 11 (8): e0158542. 
https://doi.org/10.1371/journal.pone.0158542

Oliveira C., Avelino G.S., Abe K.T., Mariguela T.C., Benine R.C., Ortí G., Vari R.P. \& Castro R.M.C. 2011. Phylogenetic relationships within the speciose family Characidae (Teleostei: Ostariophysi: Characiformes) based on multilocus analysis and extensive ingroup sampling. BMC Evolutionary Biology, 11, 275. https://doi.org/10.1186/1471-2148-11-275

Ota R.R., Carvalho F.R. \& Pavanelli C.S. 2020. Taxonomic review of the Hyphessobrycon panamensis species-group (Characiformes: Characidae). Zootaxa 4751 (3): 401-436.

https://doi.org/10.11646/zootaxa.4751.3.1

Ottoni F.P., Mattos J.L.O., Katz A.M. \& Bragança P.H.N. 2019. Phylogeny and species delimitation based on molecular approaches on the species of the Australoheros autrani group (Teleostei, Cichlidae), with biogeographic comments. Zoosystematics and Evolution 95 (1): 49-64.

https://doi.org/10.3897/zse.95.31658

Padial J.M., Miralles A., De la Riva I. \& Vences M. 2010. The integrative future of taxonomy. Frontiers in Zoology 7: 16. https://doi.org/10.1186/1742-9994-7-16

Pereira L.H.G., Pazian M.F., Hanner R., Foresti F. \& Oliveira C. 2011. DNA barcoding reveals hidden diversity in the Neotropical freshwater fish Piabina argentea (Characiformes: Characidae) from the Upper Paraná basin of Brazil. Mitochondrial DNA 22 (1): 87-96.

https://doi.org/10.3109/19401736.2011.588213

Poulakakis N., Edwards D.L., Chiari Y., Garrick R.C., Russello M.A., Benavides E., WatkinsColwell G.J., Glaberman S., Tapia W., Gibbs J.P., Cayot L.J. \& Caccone A. 2015. Description of a new Galapagos giant tortoise species (Chelonoidis; Testudines:Testudinidae) from Cerro Fatal on Santa Cruz Island. PLoS ONE 10 (10): e013877. https://doi.org/10.1371/journal.pone.0138779

Puillandre N., Lambert A., Brouillet S. \& Achaz G. 2012. ABGD, automatic barcode gap discovery for primary species delimitation. Molecular Ecology 21: 1864-1877.

https://doi.org/10.1111/j.1365-294X.2011.05239.x

Queiroz de K. 2005. Different species problems and their resolution. BioEssays 27 (12): 1263-1269. https://doi.org/10.1002/bies.20325

Queiroz de K. 2007. Species concepts and species delimitation. Systematic Biology 56 (6): 879-886. https://doi.org/10.1080/10635150701701083

Roca A.L., Georgiadis N.J., Pecon-Slattery J. \& O'Brien S.J. 2001. Genetic evidence for two species of elephant in Africa. Science 80 (293): 1473-1477. https://doi.org/10.1126/science.1059936

Rosso J.J., González-Castro M., Bogan S., Cardoso Y.P., Mabragaña E., Delpiani M. \& Astarloa J.M.D. 2018. Integrative taxonomy reveals a new species of the Hoplias malabaricus species complex (Teleostei: Erythrinidae). Ichthyological Exploration of Freshwaters IEF-1076: 1-18.

https://doi.org/10.23788/IEF-1076

Rozas J., Sánchez J.C., Messeguer X. \& Rozas R. 2003. DnaSP, DNA polymorphism analyses by the 506 coalescent and other methods. Bioinformatics 19: 2496-2497.

https://doi.org/10.1093/bioinformatics/btg359

de Santana C.D., Crampton W.G., Dillman C.B., Frederico R.G., Sabaj M.H., Covain R., Ready J., Zuanon J., Oliveira R.R., Mendes Júnior R.N.G., Bastos D.A., Teixeira T.F., Mol J., Ohara W., Castro N.C., Peixoto L.A., Nagamachi C., Sousa L., Montag L.F.A., Ribeiro F., Waddell J.C., Piorsky N.M., Vari R.P. \& Wosiacki W.B. 2019 Unexpected species diversity in electric eels with a description of the strongest living bioelectricity generator. Nature Communications 10: 4000.

https://doi.org/10.1038/s41467-019-11690-z 
Sites J.W. \& Marshall J.C. 2003. Delimiting species: A Renaissance issue in systematic biology. Trends in Ecology and Evolution 18: 462-470. https://doi.org/10.1016/S0169-5347(03)00184-8

Swofford D.L. 2002. PAUP. Phylogenetic Analysis Using Parsimony (*and Other Methods), 4.0 edn, Sinauer, Sunderland, MA.

Sytsma K.J. \& Schaal B.A. 1985. Phylogenetics of the Lisianthius skinneri (Gentianaceae) complex in Panama utilizing DNA restriction fragment analysis. Evolution 39: 594-608.

Taylor W.R. \& Van Dyke G.C. 1985. Revised procedures for staining and clearing small fishes and other vertebrates for bone and cartilage study. Cybium 9 (2): 107-120.

Ward R.D., Zemlak T.S., Innes B.H., Las, P.R. \& Hebert P.D.N. 2005. DNA barcoding Australia's fish species. Philosophical Transactions of the Royal Society of London B, Biological Sciences 360 (1462): 1847-1857. https://doi.org/10.1098/rstb.2005.1716

Weitzman S.H. 1962. The osteology of Brycon meeki, a generalized characid fish, with an osteological definition of the family. Stanford Ichthyological Bulletin 8 (1): 3-77.

Weitzman S.H. \& Palmer L. 1997. A new species of Hyphessobrycon (Teleostei: Characidae) from the Neblina region of Venezuela and Brazil, with comments on the putative 'rosy tetra clade'. Ichthyological Exploration of Freshwaters 7 (3): 209-242.

Wiens J.J. \& Penkrot T.A. 2002. Delimiting species using DNA and Morphological variation and discordant limits in spiny lizards (Sceloporus). Systematic biology 51 (1): 69-91.

https://doi.org/10.1080/106351502753475880

Xia X.H. 2013. Dambe5: a comprehensive software package for data analysis in molecular biology and evolution. Molecular Biology and Evolution 30: 1720-1728. https://doi.org/10.1093/molbev/mst064

Xia X.H., Xie Z., Salemi M., Chen L. \& Wang Y. 2003. An index of substitution saturation and its application. Molecular Phylogenetics and Evolution 26: 1-7.

https://doi.org/10.1016/S1055-7903(02)00326-3

Zhang J., Kapli P., Pavlidis P. \& Stamatakis A. 2013. A general species delimitation method with applications to phylogenetic placements. Bioinformatics 29: 2869-2876.

https://doi.org/10.1093/bioinformatics/btt499

Manuscript received: 27 April 2020

Manuscript accepted: 28 July 2020

Published on: 9 November 2020

Topic editor: Rudy Jocqué

Desk editor: Marianne Salaün

Printed versions of all papers are also deposited in the libraries of the institutes that are members of the EJT consortium: Muséum national d'histoire naturelle, Paris, France; Botanic Garden Meise, Belgium; Royal Museum for Central Africa, Tervuren, Belgium; Royal Belgian Institute of Natural Sciences, Brussels, Belgium; Natural History Museum of Denmark, Copenhagen, Denmark; Naturalis Biodiversity Center, Leiden, the Netherlands; Museo Nacional de Ciencias Naturales-CSIC, Madrid, Spain; Real Jardín Botánico de Madrid CSIC, Spain; Zoological Research Museum Alexander Koenig, Bonn, Germany; National Museum, Prague, Czech Republic. 
Appendix 1. Comparative material.

H. bentosi: MCZ 20842, 15 specs (syntypes); USNM 120270, 3 specs (syntypes); CAS 42682, 3 specs (syntypes), Óbidos; CICCAA 04788, 100, specs, Óbidos municipality, Amazon River basin, Pará state, Brazil; CICCAA 04789, 30 specs (C\&S) specs, Óbidos municipality, Amazon River basin, Pará state, Brazil. CICCAA 04790, 131, specs, Óbidos municipality, Amazon River basin, Pará state, Brazil. H. caru: CICCAA 02286, 1 spec. (holotype); CICCAA 00706, 37 specs (paratypes); CICCAA 0709, 12 specs (C\&S) (paratypes); LIOP.UFAM 1009, 1 spec. (paratypes), CICCAA00707, 3 specs (paratypes); CICCAA 00708, 2 specs (paratypes); UFRJ11745, 1 spec. (paratypes), Buriticupu municipality, Buritizinho River, Mearim River basin, Maranhão state, Brazil. - H. compressus: BMNH 1905.12.6.4-5, 2 specs (paratypes), Oaxaca state. México. - H. copelandi: CAS 42683, 5 specs (syntypes); MCZ 20771, 88 specs (syntypes); USNM 120271, 6 spms (syntypes), Tabatinga. CICCAA04834, 18 specs, Óbidos municipality, Amazon River basin, Pará state, Brazil. - H. eques: MMW 95056, 1 spec. (lectotype); NMW 62693, 6 specs (Paralectotypes); NMW59810, 2 specs (paralectotypes), Villa Bela, Óbidos; CICCAA 00715, 4 specs (C\&S); CICCAA 00710, 51 specs, Tombos municipality, Paraiba do Sul River basin, Minas Gerais state, Brazil; CICCAA 00300, 24 specs; CICCAA 00699, 7 specs, Itaberaba municipality, São Francisco River basin, Bahia state, Brazil; CICCAA03447, 5 spmcs; CICCAA03448, 6 specs, Corumbá municipality, Paraguay River basin, Mato Grosso do Sul state, Brazil. CICCAA 04791, 240; CICCAA04792, 30 specs (C\&S); CICCAA04793, 6 spmcs, Santarem municipality, Tapajós River basin, Pará State, Brazil. - H. erythrostigma: ANSP 70208, $1 \mathrm{spec}$. (holotype), Peru and Brazil. - H. epicharis: FMNH100609, 1 spec. (paratypes), Baria River, Amazonas, Venezuela. - H. haraldschultzi: CICCAA 00873, 20 specs, Ilha do Bananal municipality, Javaés River, Tocantins state, Brazil. - H. hasemani: ANSP 39230, 1 spec. (holotype), Guajaramirim municipality, Madeira River, Rondônia state, Brazil. - H. jackrobertsi: MTD F 33042, 1 spec. (holotype), Peru, vermutlich Umgebung von Iquitos; MTD F 33043-33051, 9 spmcs, Peru, vermutlich Umgebung von Iquitos; MTD F 33149-33158, 10 specs, Peru, Loreto, río Pastaza, río Chuinda, Lago de Rimachi. - H. micropterus: FMNHH 57916, 1 spec. (holotype), Lagoa de Porto, Minas Gerais state, Brazil. FMNH 57917, 14 specs (paratypes) Lagoa de Porto; FMNH 57918, 9 specs (paratypes); Santa Rita, São Francisco River basin; FMNH 57920, 25 specs (paratypes), Pirapora; FMNH 57920, 1 spec. (paratypes), Rio Salitre; FMNH 57921, 4 spec. (paratypes), Boqueirao, near mouth of Rio Preto. - H. paepkei: MTD F 33023, 1 spec. (holotype), Brasilien, Umgebung von Manaus. - H. piorskii: CICCAA 00695, 1 spec. (holotype); CICCAA 00430, 15 specs (paratypes); CICCAA 00431, 21 specs (paratypes); CICCAA 00696, 15 specs (paratypes); CICCAA 00697, 16 specs (C\&S) (paratypes); CICCAA 00698, 6 specs, 1 spec. (C\&S) (paratypes); CICCAA 00750, 9 specs (paratypes); CICCAA 01654, 1 spec. (paratypes); CICCAA 03385, [donated from CPUFMA 171664], 15 specs (paratypes); UFRJ 11553, 6 specs (paratypes), stream at the Anapurus municipality, Munim River, Maranhão state, Brazil. CICCAA 00089, 1 spec. (C\&S) (paratypes); CICCAA 00881, 1 spec. (paratype); CICCAA 01563, 1 spec. (paratype); stream at Mata de Itamacaoca, Chapadinha municipality, Munim River, Maranhão state, Brazil. CICCAA 01382, 5 specs (paratypes); CICCAA 02008, 12 (C\&S) specs (paratype), stream at Mata Fome, Barreirinhas municipality, Preguiças River, Maranhão state, Brazil. - H. pyrrhonotus: MZUSP 45714, 1 spec. (holotype), Ereré River, Brazil. - H. rosaceus: FMNH 52791, 1 spec. (holotype), Gluck Island, Essequibo River, Guyana. - H. werneri: MZUSP 42365, 1 spec. (holotype), Santa Maria do Pará and São Miguel do Guamá municipality, Guamá River, Pará state, Brazil. CICCAA 00751, 1 spec., Paragominas municipality, Candiru River, Pará state, Brazil. - H. socolofi: MZUSP 13181, 1 spec. (holotype), Barcelos municipality, Negro River, Amazonas state, Brazil. 
Appendix 2. List of nucleotide substitutions (synapomorphies and autapomorphies) from each lineage (species) and some crucial points of the cladogram of the Fig. 7B.

A (Hyphessobrycon copelandi clade) - COI $90(\mathrm{C} \rightarrow \mathrm{A})$, COI $126(\mathrm{~A} \rightarrow \mathrm{G}), \mathrm{COI} 138(\mathrm{C} \rightarrow \mathrm{T}), \mathrm{COI} 189$ $(\mathrm{C} \rightarrow \mathrm{T})$, COI $192(\mathrm{~T} \rightarrow \mathrm{A}), \mathrm{COI} 237(\mathrm{C} \rightarrow \mathrm{T}), \mathrm{COI} 264(\mathrm{~T} \rightarrow \mathrm{C}), \mathrm{COI} 282(\mathrm{C} \rightarrow \mathrm{T}), \mathrm{COI} 285(\mathrm{C} \rightarrow \mathrm{A}), \mathrm{COI}$ $312(\mathrm{~T} \rightarrow \mathrm{C})$, COI $384(\mathrm{C} \rightarrow \mathrm{T})$, COI $402(\mathrm{~A} \rightarrow \mathrm{G})$, COI $429(\mathrm{~A} \rightarrow \mathrm{G}), \mathrm{COI} 435(\mathrm{~A} \rightarrow \mathrm{G}), \mathrm{COI} 486(\mathrm{~T} \rightarrow \mathrm{C})$, $\mathrm{COI} 522(\mathrm{~A} \rightarrow \mathrm{G})$, COI $525(\mathrm{C} \rightarrow \mathrm{T})$, COI $547(\mathrm{C} \rightarrow \mathrm{T})$, COI $582(\mathrm{~T} \rightarrow \mathrm{C})$, COI $621(\mathrm{~T} \rightarrow \mathrm{C})$, COI 624 $(\mathrm{A} \rightarrow \mathrm{G})$, COI $678(\mathrm{~T} \rightarrow \mathrm{C})$, COI $684(\mathrm{~A} \rightarrow \mathrm{C})$, COI $690(\mathrm{~T} \rightarrow \mathrm{C})$, COI $696(\mathrm{~A} \rightarrow \mathrm{G})$. B $($ all the species except $H$. aff. copelandi $)$ - COI $162(\mathrm{C} \rightarrow \mathrm{T})$, COI $270(\mathrm{~A} \rightarrow \mathrm{C})$, COI $276(\mathrm{G} \rightarrow \mathrm{A})$, COI $363(\mathrm{G} \rightarrow \mathrm{A})$, $\mathrm{COI} 681(\mathrm{C} \rightarrow \mathrm{T})$. C $($ H. aff. copelandi $)-\mathrm{COI} 93(\mathrm{G} \rightarrow \mathrm{A}), \mathrm{COI} 114(\mathrm{G} \rightarrow \mathrm{A}), \mathrm{COI} 132(\mathrm{~T} \rightarrow \mathrm{C}), \mathrm{COI} 228$ $(\mathrm{A} \rightarrow \mathrm{G}), \mathrm{COI} 244(\mathrm{C} \rightarrow \mathrm{T}), \mathrm{COI} 246(\mathrm{G} \rightarrow \mathrm{A}), \mathrm{COI} 330(\mathrm{C} \rightarrow \mathrm{T}), \mathrm{COI} 336(\mathrm{C} \rightarrow \mathrm{A}), \mathrm{COI} 414(\mathrm{~T} \rightarrow \mathrm{C}), \mathrm{COI}$ $591(\mathrm{~A} \rightarrow \mathrm{G})$, COI $672(\mathrm{~T} \rightarrow \mathrm{C})$. D $($ H. geryi sp. nov. $)$ - COI $225(\mathrm{~T} \rightarrow \mathrm{C})$, COI $228(\mathrm{~A} \rightarrow \mathrm{C})$, COI 321 $(\mathrm{G} \rightarrow \mathrm{A})$, COI $522(\mathrm{G} \rightarrow \mathrm{A})$, COI $534(\mathrm{G} \rightarrow \mathrm{A})$, COI $543(\mathrm{~A} \rightarrow \mathrm{G})$, COI $589(\mathrm{C} \rightarrow \mathrm{T})$, COI $615(\mathrm{G} \rightarrow \mathrm{A})$. $\mathbf{E}($ H. frickei sp. nov. + H. copelandi) - COI $231(\mathrm{~T} \rightarrow \mathrm{C})$, COI $315(\mathrm{~A} \rightarrow \mathrm{G}), \mathrm{COI} 345(\mathrm{~A} \rightarrow \mathrm{C}), \mathrm{COI} 375$ $(\mathrm{G} \rightarrow \mathrm{A})$, COI $402(\mathrm{G} \rightarrow \mathrm{A})$, COI $405(\mathrm{~T} \rightarrow \mathrm{C})$, COI $528(\mathrm{~A} \rightarrow \mathrm{G})$, COI $558(\mathrm{~A} \rightarrow \mathrm{G})$, COI $609(\mathrm{~A} \rightarrow \mathrm{G})$. F (H. frickei sp. nov.) - COI $126(\mathrm{G} \rightarrow \mathrm{A})$, COI $141(\mathrm{G} \rightarrow \mathrm{C})$, COI $291(\mathrm{~A} \rightarrow \mathrm{G})$, COI $300(\mathrm{~A} \rightarrow \mathrm{G}), \mathrm{COI}$ $345(\mathrm{C} \rightarrow \mathrm{G})$, COI $366(\mathrm{C} \rightarrow \mathrm{T}), \mathrm{COI} 435(\mathrm{G} \rightarrow \mathrm{A}), \mathrm{COI} 510(\mathrm{~T} \rightarrow \mathrm{C}), \mathrm{COI} 633(\mathrm{~T} \rightarrow \mathrm{C}), \mathrm{COI} 657(\mathrm{C} \rightarrow \mathrm{T})$, COI $672(\mathrm{~T} \rightarrow \mathrm{C})$. G $($ H. copelandi $)-\mathrm{COI} 84(\mathrm{~A} \rightarrow \mathrm{G})$, COI $246(\mathrm{G} \rightarrow \mathrm{A})$, COI $282(\mathrm{~T} \rightarrow \mathrm{C})$, COI 321 $(\mathrm{G} \rightarrow \mathrm{T}), \mathrm{COI} 339(\mathrm{~A} \rightarrow \mathrm{G})$, COI $375(\mathrm{~A} \rightarrow \mathrm{C}), \mathrm{COI} 417(\mathrm{~A} \rightarrow \mathrm{G}), \mathrm{COI} 429(\mathrm{G} \rightarrow \mathrm{A})$, COI $450(\mathrm{~T} \rightarrow \mathrm{C}), \mathrm{COI}$ $504(\mathrm{~T} \rightarrow \mathrm{C})$, COI $663(\mathrm{C} \rightarrow \mathrm{T})$. 